\title{
Evaluation of Synthesized Magnetic Nanoparticles and Salicylic Acid Effects on Improvement of Antioxidant Properties and Essential Oils of Calotropis Procera Hairy Roots and Seedlings
}

\author{
Fatemeh Adabavazeh \\ Shahid Bahonar University of Kerman \\ Shahram Pourseyedi ( $\nabla$ spseyedi@uk.ac.ir) \\ Shahid Bahonar University of Kerman \\ Nazi Nadernejad \\ Shahid Bahonar University of Kerman \\ Roya Razavizadeh \\ Payame Noor University \\ Hossein Mozafari \\ Graduate University of Advanced Technology
}

\section{Research Article}

Keywords: Antioxidant responses, Calotropis procera, Essential oil, Hairy roots, Magnetic nanoparticles, Salicylic acid

Posted Date: February 1st, 2022

DOI: https://doi.org/10.21203/rs.3.rs-1297037/v1

License: @(1) This work is licensed under a Creative Commons Attribution 4.0 International License. Read Full License 


\section{Abstract}

Calotropis procera presents high levels of medicinally important terpenes and phenolics with antiinflammatory, antimicrobial, and antioxidant properties. The present study aimed to develop a suitable platform for mass production of pharmacological metabolites and improvement of antioxidant activity of $C$. procera. Motivated by such aim, potential effects of magnetic nanoparticles (MNPs) and salicylic acid (SA) on antioxidant defense response and essential oils in seedlings and hairy roots were investigated. 21-day-old seedlings were treated by five levels of MNPs $\left(0,50,100,150\right.$, and $\left.200 \mathrm{mg} \mathrm{L}^{-1}\right)$ and three SA concentrations $(0.0,0.05,0.1 \mathrm{mM})$. Moreover, the hairy roots about $2 \mathrm{~cm}$ were transferred into MS liquid medium supplemented with the above-mentioned concentrations of MNPs and 0 and $0.01 \mathrm{mM} \mathrm{SA}$. After treatment, total phenolics, flavonoids, flavonol, anthocyanin, activity of polyphenol oxidase and L-phenylalanine ammonia-lyase, ferric-reducing antioxidant power, 2, 2-diphenyl-1-picrylhydrazyl and production of essential oils were analyzed. Our results demonstrated that hairy root culture is a powerful alternative for improving and inducing secondary metabolites of $C$. procera as compared to seedlings. Moreover, it was found that MNPs combined with SA have the more ability than all other treatments to improve antioxidant activity and essential oil in both seedlings and hairy roots. Here, 100 and $200 \mathrm{mg} \mathrm{L}^{-1}$ MNPs combined with $0.01 \mathrm{mM} \mathrm{SA}$ had more pronounced impact on induction of pharmacological constituents and antioxidant activity. Results suggest that MNPs and SA in hairy root culture can bring great insights into development in vitro biosynthesis of valuable secondary metabolites.

\section{Introduction}

Calotropis procera, known as stabragh, is a species of flowering plant in the family Apocynaceae that its medicinal potential has been known to traditional medicine. It is widely grown in Iran, Indonesia, tropical and North Africa, Western and South Asia. It is wellknown for its therapeutic properties as an anti-inflammatory, antimicrobial, antioxidant, anti-asthmatic anticancerous, and analgesic substance (Murti et al. 2010). These pharmaceutical traits are plausibly attributed to major plant secondary metabolites. Hence, regarding the pharmacological importance of $C$. procera, improving and increasing of natural pharmacological metabolites by reproducible alternative approaches seems to be necessary.

Over recent years, hairy roots cultures is of paramount importance in enhancing the production of secondary metabolites due to the genetic and biochemical stability, their rapid growth, low doubling time, eases of maintenance, and the preservation of the same properties of the mother plant. The high potential of hairy root cultures to enhance production of high-compounds has been already reported in many plant species (Kastell et al. 2015; Thiruvengadam et al. 2014). Nevertheless, various strategies have been recently employed to improve the performance of hairy roots in increasing plant metabolite production. A number of scientific articles suggest that elicitation through the application of biotic and abiotic components in hairy root media is one of the most practical (Hedayati et al. 2020; Thilip et al. 2019). Accordingly, in this study, iron oxide nanoparticles (NPs) and salicylic acid (SA) are considered as promising new abiotic elicitors to improve the metabolites of $C$. procera.

Iron oxide NPs with a special surface cover of magnetic particles, which have to be harmless and biocompatible, are constant, less toxic, and less expensive, as compared with their native bulk compounds of the same materials (Wannoussa et al. 2015). Iron, as one of the most distinguished constituents of several enzymes and an activator for metabolic processes, is an irreplaceable element in virtually all living organisms. Besides, it has already demonstrated that iron tends to be a potent toxin responsible for the overproduction of highly reactive oxygen species that lead to enhanced oxidative stress (Sharma et al. 2012). These characters make it acts as a potent elicitor for the enhanced production of desired secondary metabolites when added exogenously in culture media. However metal and metal oxides NPs because of their small size, the large specific surface area, high reactivity, great subcellular transportation, and high bioavailability can be rapidly absorbed and exhibit different physiochemical properties which are not present in naturally occurring materials (Rastogi et al. 2017).

Further, salicylic acid (SA) is thought to be another feasible approach to boost the biosynthesis of special secondary metabolites, as well as minimize the possible adverse effects of iron oxide NPs because of its signaling role in plant defense responses and the increase in cycle growth and nutrients uptake (Idrees et al. 2010).

To the best of our knowledge, no previous study has been performed regarding improving bioactive compound production and antioxidant activities of $C$. procera, as a valuable medicinal herb native to Iran. Hence, this study aimed to provide an efficient method to improve and increase production of the plant antioxidants and valuable metabolites. For this purpose, a comparative

Page $2 / 21$ 
study of the effects of $\mathrm{Fe}_{3} \mathrm{O}_{4}$ magnetic nanoparticles (MNPs) and SA on enhanced secondary metabolites and antioxidant responses between seedlings and hairy roots of C.procera was carried out. Here, hydroponic culture was considered for seedlings growth as a feasible alternative to traditional soil cultivation not only for having a large scale of uniform seedlings with high percentage of bioactive substances, but also for the faster growth. Furthermore, in order to avoid any possible toxicity of synthetic NPs, iron nanoparticle was synthesized by $C$. procera leaf extract.

\section{Material And Methods}

\section{Seed culture and preparation of explants}

Seeds of Calotropis procera were collected from wild-growing plant populations in Shahdad located in the Kerman province in the southeastern region of Iran $\left(30^{\circ} 25^{\prime} 03^{\prime \prime} \mathrm{N} 57^{\circ} 42^{\prime} 24^{\prime \prime} \mathrm{E}\right)$. Surface sterilization was carried out using ethanol $70 \%$ ( $\mathrm{v} / \mathrm{v}$ ) for $20 \mathrm{~s}$ and $20 \%$ $(\mathrm{v} / \mathrm{v})$ of commercial bleach solution (5\% active chlorine sodium hypochlorite; Sigma-Aldrich ${ }^{\circledR}$, St. Louis, MO) for 10 min. After washing several times with sterile water under laminar air-flow hood, the seeds were cultured in $1 / 4$ Murashige and Skoog nutrient medium (MS) (Murashige and Skoog 1962) containing $7.5 \mathrm{~g} \mathrm{~L}^{-1}$ sucrose (Merck, Darmstadt, Germany) and kept in the growth

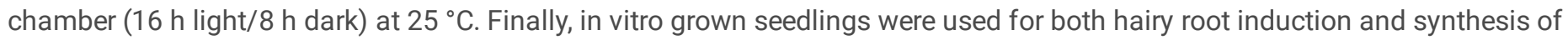
magnetic nanoparticles.

\section{Establishment of hairy roots}

21-day-old seedlings of $C$. procera were used as a source of explants. Leaf explants were aseptically cut into small sections about $1 \mathrm{~cm}$ and wounded by sterile syringes. Then, these explants were immersed in an inoculation suspension consists of the pellet of Agrobacterium rhizogenes strain A4 resuspended in $1 / 2$ MS mediums with $6 \%$ sucrose and shaken for 30 min in the rotary shake. After that, they were blotted on sterile filter paper and transferred to hormone free MS basal medium supplemented with $30 \mathrm{~g} \mathrm{~L}^{-1}$ sucrose, and $8 \mathrm{~g} \mathrm{~L}^{-1}$ agar-agar (Merck) ( $\left.\mathrm{pH}=5.7\right)$. After $48 \mathrm{~h}$ of incubation in dark at $25 \pm 2{ }^{\circ} \mathrm{C}$, all explants were washed with sterile water containing $600 \mathrm{mg} \mathrm{L}^{-1}$ cefotaxime, dried with sterile filter paper and placed on the MS medium supplemented with $600 \mathrm{mg} \mathrm{L}^{-}$ ${ }^{1}$ cefotaxime antibiotic to remove the bacteria. All co-cultured explants were incubated under dark conditions at $25 \pm 2{ }^{\circ} \mathrm{C}$ for $48 \mathrm{~h}$. Thereafter, explants were sub-cultured in fresh MS medium every weeks and cefotaxime concentration was gradually reduced in subsequent subcultures from 600 to $100 \mathrm{mg} \mathrm{L}^{-1}$. Finally, the one-month old hairy roots were transferred to MS liquid medium and incubated on a shaker at $120 \mathrm{rpm}$ under dark condition at $28^{\circ} \mathrm{C}$.

\section{Hairy roots and seedlings treatment by abiotic elicitor}

\section{Elicitor preparation}

MNPs and SA were used in elicitation process. The SA stock solution (1000 $\mathrm{mg} \mathrm{L}^{-1}$ ) was prepared by dissolving $100 \mathrm{mg} \mathrm{SA} \mathrm{(Merck)}$ in $100 \mathrm{~mL}$ distilled water, and then sterilized by autoclaving.

MNPs were synthesized in average size about $11 \mathrm{~nm}$ using leaf extract of $C$. procera, iron (III) chloride and iron (II) as the precursor. For preparation of leaf extract, $1 \mathrm{~g}$ of dried plant powder obtained from 30 days old seedlings was heated at $60^{\circ} \mathrm{C}$ for 1 hour along with continuous stirring on magnetic stirrer. After centrifugation of the homogenate at $15000 \mathrm{rpm}$ for $20 \mathrm{~min}$, the supernatant was filtered with Whatman number 1 paper (Whatman, Maidstone, UK). The superparamagnetic $\mathrm{Fe}_{3} \mathrm{O}_{4} \mathrm{NPs}$ were synthesized according to the chemical co-precipitation, following the procedure of Yang et al. (2009) with slight modification. Briefly, 0.04 mol iron (III) chloride and $0.02 \mathrm{~mol}$ iron (II) were dissolved in $120 \mathrm{~mL}$ distilled water and heated at $60{ }^{\circ} \mathrm{C}$ under a $\mathrm{N}_{2}$ atmosphere with vigorous mechanical stirring. Then, $1500 \mu \mathrm{L}$ the aqueous solutions of $C$. procera extract and $10 \mathrm{~mL}$ of ammonia solution $25 \%$ was quickly added to the mixture. The mixture was heated to $60^{\circ} \mathrm{C}$ for $1 \mathrm{~h}$ under the same conditions. After cooling to room temperature, the obtained NPs were collected magnetically, washed, and dispersed in $200 \mathrm{~mL}$ of $0.3 \mathrm{M}$ trisodium citrate solution and heated at $80{ }^{\circ} \mathrm{C}$ for $1 \mathrm{~h}$. Finally, the precipitate was gathered using an external magnet and washed with acetone to eliminate the remaining trisodium citrate. Finally, the MNPs were dried at $60^{\circ} \mathrm{C}$ for $24 \mathrm{~h}$ (Ghasemi et al. 2019). After sterilizing of synthesized MNPs under laminar airflow hood for 20 minutes, a solution of $1000 \mathrm{mg} \mathrm{L}^{-1}$ of MNPs was prepared in sterile water.

\section{Seedlings treatment}


The mature and sterilized seeds of $C$. procera were germinated on moist filter paper in petri dishes at $25^{\circ} \mathrm{C}$. After 10 days, uniform seedlings were transferred to hydroponic system with Hoagland solution and were grown in the growth chamber at $25^{\circ} \mathrm{C}$ with a $16-\mathrm{h}$ photoperiod provided by white fluorescent lamps at a light intensity of $90 \mu \mathrm{mol} \mathrm{m} \mathrm{m}^{-2} \mathrm{~s}^{-1}$ (Osram Sylvania, Versailles, KY). According to method of Bastani et al. (2018) with slight modification, after the emergence of 4 to 6 leaves of the plant, different concentrations $\left(0,50,100,150\right.$, and $\left.200 \mathrm{mg} \mathrm{L}^{-1}\right)$ of MNPs solution were sprayed on the leaves (seven times during two weeks to avoid leaf damage). Also, different concentrations of SA $(0,0.01,0.05$ and $0.1 \mathrm{mM})$ were added to Hoagland solution. Since no statistical significant difference was observed between the control $(0.0 \mathrm{mM})$ and $0.01 \mathrm{mM} \mathrm{SA}$ application sliced across different concentrations $(0,50$ and $100 \mathrm{mg} \mathrm{L}^{-1}$ ) of MNPs, data for the application of $0.01 \mathrm{mM}$ were set aside and the experiment was continued with the application of 0, 0.05 and $0.1 \mathrm{mM}$ SA. Finally, after two weeks of the treatment, total phenolics, flavonoids, anthocyanin, flavonol, activities of enzymes polyphenol oxidase (PPO) and L-phenylalanine ammonia-lyase (PAL), ferric-reducing antioxidant power (FRAP), 2,2-diphenyl-1-picrylhydrazyl (DPPH) and content of essential oils were measured.

\section{Hairy roots treatment}

First, the root pieces about $2 \mathrm{~cm}$, obtained from four weeks old hairy roots of $C$. procera, were cultured in $50 \mathrm{~mL}$ of MS liquid medium supplemented with different concentrations $0,50,100,150$, and $200 \mathrm{mg} \mathrm{L}^{-1} \mathrm{MNPs}$ and $0,0.01$ and $0.05 \mathrm{mM} \mathrm{SA}$. All cultures were incubated for $72 \mathrm{~h}$ on an orbital shaker at $120 \mathrm{rpm}$ under continuous darkness at $28^{\circ} \mathrm{C}$. Subsequently, all samples washed several times with sterile water under laminar air-flow hood, transferred into elicitor-free MS liquid medium and kept in aforementioned condition for 21 days. Data related to jars with $0.05 \mathrm{mM} \mathrm{SA}$ application were removed due to growth arrest and the experiment was continued with 0.0 and $0.01 \mathrm{mM} \mathrm{SA}$ application (Fig. 1). Then, like seedlings, the above-mentioned traits were analyzed.

\section{Determination of total phenolic content}

Total phenolic content was determined utilizing 95\% (v/v) ethanol based on Ronald and Laima's (1999) method. After homogenizing $0.1 \mathrm{~g}$ of leaf and hairy roots in $5 \mathrm{~mL}$ of $95 \%(\mathrm{v} / \mathrm{v})$ ethanol, this solution was kept for $72 \mathrm{~h}$ in the dark at $25^{\circ} \mathrm{C}$. The extract was centrifuged at $4000 \mathrm{rpm}$ for $10 \mathrm{~min}$ at $25^{\circ} \mathrm{C}$. Then, $1 \mathrm{~mL}$ supernatant was mixed with $1 \mathrm{~mL}$ of ethanol $95 \%(\mathrm{v} / \mathrm{v}), 1 \mathrm{~mL}$ of $5 \%(\mathrm{w} / \mathrm{v})$ aqueous sodium carbonate, $3 \mathrm{~mL}$ of distilled water, and $0.5 \mathrm{~mL}$ of $50 \%(\mathrm{v} / \mathrm{v})$ Folin-Ciocalteu phenol reagent (Merck) and kept for $1 \mathrm{~h}$ in the dark at $25^{\circ} \mathrm{C}$. Afterwards, the absorbance of each sample was determined at $725 \mathrm{~nm}$ using a UV-visible spectrophotometer (U6305 model, Jenway, UK). A standard curve was developed using gallic acid (Merck) and results were reported as mg of gallic acid $\mathrm{g}$ ${ }^{1} \mathrm{FW}$.

\section{Determination of total flavonoids and flavonol content}

Total flavonoid content was analyzed using the aluminum chloride colorimetric method reported by Meda et al. (2005). In this method, $0.2 \mathrm{~g}$ of fresh tissue (leaf and hairy root) was homogenized with $3 \mathrm{~mL}$ acidified methanol (Methanol: Acetic acid glacial 99: $1 \mathrm{v} / \mathrm{v}$ ). After centrifuging at $10000 \mathrm{rpm}$ for $15 \mathrm{~min}, 0.5 \mathrm{~mL}$ of the supernatant was mixed with $0.1 \mathrm{~mL}$ of $10 \%$ (w/v) aluminum chloride $\left(\mathrm{AlCl}_{3}\right)$ solutions, and $0.1 \mathrm{~mL}$ of $1 \mathrm{M}$ potassium acetate, $1.5 \mathrm{~mL}$ of $80 \%(\mathrm{v} / \mathrm{v})$ methanol and $2.8 \mathrm{~mL}$ distilled water. Then, the mixture was incubated at $25^{\circ} \mathrm{C}$ for $30 \mathrm{~min}$, followed by the measurement of absorbance at $415 \mathrm{~nm}$ against the blank.

The content of total flavonol content in plant methanolic extracts was estimated by Miliauskas et al. (2004). $1 \mathrm{~mL}$ of sample was mixed with $1 \mathrm{~mL} \mathrm{AlCl}(2 \% \mathrm{w} / \mathrm{v})$ and $3 \mathrm{ml}$ sodium acetate $(5 \% \mathrm{w} / \mathrm{v})$. The absorbance was read at $440 \mathrm{~nm}$ after incubation at $250{ }^{\circ} \mathrm{C}$ for $2.5 \mathrm{~h}$.

Quercetin (Merck) solutions in methanol were used for constructing the standard curve. The result was expressed as $\mu \mathrm{g} \mathrm{g}^{-1} \mathrm{FW}$.

\section{Determination of anthocyanin content}

Anthocyanin was assayed by adapting the modified Wagner's (1979) method using acidified methanol (Methanol: HCl 99: $1 \mathrm{v} / \mathrm{v}$ ). 0.1 $\mathrm{g}$ of leaf and hairy root were homogenized in $5 \mathrm{~mL}$ of acidified methanol and kept at $25^{\circ} \mathrm{C}$ for $24 \mathrm{~h}$ in the dark. After centrifugation of the homogenate at $4000 \mathrm{rpm}$ for10 min at room temperature, the absorbance of each supernatant was measured at $550 \mathrm{~nm}$. The extinction coefficient $33,000\left(\mathrm{mM}^{-1} \mathrm{~cm}^{-1}\right)$ was used to calculate the amount of total anthocyanin expressed as $\mu \mathrm{mol} \mathrm{g}{ }^{-1} \mathrm{FW}$.

\section{Determination of phenylalanine ammonialyase (PAL)}


$0.2 \mathrm{~g}$ leaf and hairy root were extracted with $50 \mathrm{mM}$ Tris-HCl buffer $(\mathrm{pH}=8.8)$ containing $15 \mathrm{mM}$ 2- $\beta$-mercaptoethanol. The mixture was centrifuged at $15000 \mathrm{rpm}$ for $30 \mathrm{~min}$ at $4^{\circ} \mathrm{C}$. The clear supernatant was assayed for PAL activity under standard conditions (Goldson et al.2008). PAL activity was analyzed according to Zucker (1965). The reaction mixture contained $1 \mathrm{~mL}$ of $50 \mathrm{mM} \mathrm{Tris-HCl}$ buffer ( $\mathrm{pH}=8.8$ ), $100 \mu \mathrm{L}$ of enzyme extract, $500 \mu \mathrm{L}$ of $10 \mathrm{mM} \mathrm{L}$-phenylalanine (Merck), and $500 \mu \mathrm{L}$ deionized water. After $1 \mathrm{~h}$ of incubation at $37^{\circ} \mathrm{C}$, the reaction was stopped by the addition of $100 \mu \mathrm{L}$ of $6 \mathrm{M} \mathrm{HCl}$. Increase in absorbance due to PAL activity was recorded at $290 \mathrm{~nm}$. The activity was expressed as unit $\mathrm{mg}^{-1}$ protein.

\section{Determination of polyphenol oxidase (PPO)}

For enzyme extraction, $0.2 \mathrm{~g}$ of fresh tissue (leaf and hairy root) was homogenized with $3 \mathrm{~mL} 50 \mathrm{mM}$ sodium phosphate buffer ( $\mathrm{pH}=6.8$ ) containing $0.1 \mathrm{M}$ ethylenediaminetetraacetic acid (Merck). After centrifugation of the homogenate at $12000 \mathrm{rpm}$ for $15 \mathrm{~min}$ at $4^{\circ} \mathrm{C}$, the supernatant was collected for the enzyme assay, described as follows.

The activity of PPO was estimated by adding $200 \mu \mathrm{L}$ of the extracts to a mixture of $0.1 \mathrm{M}$ phosphate buffer ( $\mathrm{pH}=7$ ) and $25 \mathrm{mM} \mathrm{4-}$ methylcatechol (Sigma-Aldrich), following the procedure of Cosetang and Lee (1978) with slight modification. The absorbance was measured at $420 \mathrm{~nm}$. The reaction time for PPO was $1 \mathrm{~min}$, and the activity was reported as unit $\mathrm{mg}^{-1} \mathrm{protein}_{\text {. }}$

\section{Determination ferric-reducing antioxidant power (FRAP)}

The antioxidant capacity of plant extracts was determined employing iron reduction according to method of Hu et al. (2016). For this purpose, $0.2 \mathrm{~g}$ of fresh tissue (leaf and hairy root) was homogenized with $3 \mathrm{~mL}$ methanol. After centrifugation of the homogenate at $12000 \mathrm{rpm}$ for $20 \mathrm{~min}$ at $4^{\circ} \mathrm{C}, 2.5 \mathrm{~mL}$ of the supernatant was added to $2.5 \mathrm{~mL}$ of $0.2 \mathrm{M}$ sodium phosphate buffer $(\mathrm{pH}=6.6)$ and 2.5 $\mathrm{mL}$ of $1 \%(\mathrm{w} / \mathrm{v})$ potassium ferricyanide (Merck). Blank samples were established for both methanol and deionized water-extracted controls. The samples and blanks were kept in a water bath for $20 \mathrm{~min}$ at $50^{\circ} \mathrm{C}$. After being warmed, $2.5 \mathrm{~mL}$ of $10 \%(\mathrm{w} / \mathrm{v})$ trichloro acetic acid (Merck) was added to the reaction mixtures. All reaction mixtures were, then, centrifuged at $12000 \mathrm{rpm}$ for $20 \mathrm{~min}$ at $4^{\circ} \mathrm{C}$. Finally, $5 \mathrm{~mL}$ of the supernatant was mixed with $5 \mathrm{~mL}$ of deionized water and $1 \mathrm{~mL}$ of $0.1 \%(\mathrm{w} / \mathrm{v})$ ferric chloride (w) and their absorbance was measured at $700 \mathrm{~nm}$ against a blank utilizing a spectrophotometer.

\section{Determination of 2, 2-diphenyl-1-picrylhydrazyl (DPPH)}

The DPPH radical scavenging was carried out according to the Wu and Wang (2009) with slight modifications. At first, $0.2 \mathrm{~g}$ of plant sample was extracted with $3 \mathrm{~mL}$ methanol. The extracts were centrifuged at $12000 \mathrm{rpm}$ for $20 \mathrm{~min}$ at $4^{\circ} \mathrm{C}$. After preparation of plant extracts, $20 \mu \mathrm{L}$ of each extract was added to $180 \mu \mathrm{L}$ of a $100 \mu \mathrm{M}$ DPPH methanol solution. The mixed liquid was shook forcefully and allowed to react at room temperature. After $30 \mathrm{~min}$, the absorbance of the sample was measured at $517 \mathrm{~nm}$ by spectrophotometer.

\section{Determination of essential oils}

Gas chromatography-mass spectrometry (GC/MS) was used for identification of essential oil components in $C$. procera. For this purpose, a Hewlett-Packard 5890 GC (Hewlett Packard, Waldbronn, Germany), provided with a flame ionization detector (HP-5970 mass-selective detector) and a $50 \mathrm{~m} \times 0.20 \mathrm{~mm} \mathrm{HP}-5$ (cross-linked phenyl-methyl silicon) column with $0.25 \mu \mathrm{m}$ film thickness was selected. The FID was kept at $250^{\circ} \mathrm{C}$, temperature program was $100-250^{\circ} \mathrm{C}$ with changes of $4{ }^{\circ} \mathrm{C} \mathrm{min}{ }^{-1}$ and ionization energy was 70 eV. Helium was utilized as carrier gas, the flow through the column was $1 \mathrm{~mL} \mathrm{~min}{ }^{-1}$, and the split ratio was set to 100:1. Identification was established upon sample retention time and mass recorded (Li et al. 2009; Davies 1990).

\section{Statistical analysis}

All experiments were conducted in an entirely random design with three replicates, and results were given as averages \pm standard deviations. One-way analysis of variance (ANOVA) with Duncan's tests was used to determine significant differences between multiple groups of data at the $5 \%$ level.

\section{Result}

\section{MNPs characterization}


The synthesized magnetic nanoparticles were characterized by scanning electron microscopy (SEM), transmission electron microscopy (TEM), atomic force microscope (AFM), dynamic light scattering (DLS), X-ray diffraction (XRD), and vibrating sample magnetometer (VSM). The size and morphology of MNPs were characterized using SEM and TEM. SEM image demonstrated that the MNPs are almost spherical in shape and have a narrow size distribution (Fig. 2A). The TEM image of the MNPs confirmed these results in more details and it also showed that the average size of MNPs was approximately $11 \mathrm{~nm}$ with a low aggregation (Fig. 2B). To investigate the morphology and microstructure of MNPs, AFM experiments were also employed. AFM images in Fig. 2C-D indicate two -dimensional (2D) and three-dimensional (3D) topographies of MNPs, respectively. In addition, DLS was performed to obtain the size and surface charge of nanoparticles. As shown in Fig. 2E, the average diameter of the MNPs was about $61 \mathrm{~nm}$, which was greater than the diameters obtained by TEM. It was due to the hydration of the nanoparticles in the aqueous solution which was consistent with previous studies (Ghasemi et al. 2019). Also, XRD patterns shown in Fig. 2F confirmed the crystal structures of the synthesized MNPs. The significant peaks of iron oxide particles were observed in $2 \theta=18.4,30.27,35.65,37.30,43.34,47.45,53.77$, $57.33,62.96,66.20,67.27$ and 71.44 which was consistent with the ICSD standard pattern (NO. 158745) and assigned the crystalline structure of MNPs. VSM curve was obtained to quantify of field dependent magnetism of the nanoparticles (Fig. 2G). The absence of a hysteresis loop in the magnetization curve confirmed the super-paramagnetic characteristic for MNPs with saturation magnetization of $61.10 \mathrm{emu} / \mathrm{g}$.

\section{Effect of magnetic nanoparticles and salicylic acid on total phenolic, flavonoids, flavonol, and anthocyanin content}

It was clearly observed from Fig. 3 that MNPs and SA effected significantly on the total phenolic content of hairy roots and seedlings of $C$. procera. In comparison with nontreated control, both SA concentrations under MNPs treatments prompted a notable increase in the total phenolic content of leaf, whereas SA alone had no significant effects on this content. Moreover, concentrations $\leq 100 \mathrm{mg}$ $\mathrm{L}^{-1}$ of MNPs increased this content by about 1.5 times higher than that of the control. The highest phenolic content $(2.2$ fold increase) was found when seedlings were subjected to $200 \mathrm{mg} \mathrm{L}^{-1} \mathrm{MNPs}$ and $0.1 \mathrm{mM}$ SA treatment as compared with control (Fig. 3A). The results also showed that 150 and $200 \mathrm{mg} \mathrm{L}^{-1}$ MNPs under $0.01 \mathrm{mM}$ SA treatment induced an increase in the phenolic content of hairy roots, while these MNPs concentrations alone decreased it in compare to the control sample (Fig. 3B). The highest increase in this content of hairy roots was observed at $200 \mathrm{mg} \mathrm{L}^{-1} \mathrm{MNPs}$ and $0.01 \mathrm{mM}$ SA treatment by $34 \%$.

Flavonoid content in seedlings and hairy roots of $C$. copticum was increased by all treatments tested. The highest content of flavonoid achieved by $69.5 \%$ and $98.5 \%$ in seedlings during interaction between $200 \mathrm{mg} \mathrm{L}^{-1}$ MNPs and $0.1 \mathrm{mM} \mathrm{SA}$, and in hairy roots at $100 \mathrm{mg} \mathrm{L}^{-1}$ MNPs and 0.01 SA treatments, respectively, compared with that of the controls (Fig. 3C-D).

For flavonol, results revealed that the maximum content in seedlings was obtained for treatments at 100,150 and $200 \mathrm{mg} \mathrm{L}^{-1} \mathrm{MNPs}$ with $0.1 \mathrm{SA}$, which was 1.2 times higher than that of control sample (Fig. 3E). Also, hairy roots received $200 \mathrm{mg} \mathrm{L}^{-1} \mathrm{MNPs}$ combined with 0.01 SA had significantly higher flavonol content when compared to controls (by $45.3 \%$ over control), while the content of flavonol was lowered by $18.47 \%$ in the hairy roots treated by $200 \mathrm{mg} \mathrm{L}^{-1}$ MNPs alone (Fig. 3F).

Also, the MNPs and SA applications showed the significant effect for anthocyanin content in all samples. The both SA treatments alone increased anthocyanin content of seedlings about 1.2 fold more than the control (Fig. 3G). However, no significant difference was observed between 0.05 and $0.1 \mathrm{mM}$ SA application. In addition, this content further increased when SA was applied with MNPs, compared with that in SA treatments alone. For instance, $0.1 \mathrm{mM} \mathrm{SA}$ treatment with $200 \mathrm{mg} \mathrm{L}^{-1} \mathrm{MNPs}$ increased anthocyanin by $66 \%$, while $0.1 \mathrm{mM} \mathrm{SA}$ alone induced an increase by $28.7 \%$ relative to the control. Nevertheless, the highest level of anthocyanin was observed at $200 \mathrm{mg} \mathrm{L}^{-1}$ MNPs by $71.5 \%$ in comparison with the control. Like seedlings, a similar trend in the anthocyanin content was observed in the hairy roots (Fig. $3 \mathrm{H}$ ). This content increased gradually with an increase in the concentration of MNPs. Adding of SA with $200 \mathrm{mg} \mathrm{L}^{-1}$ MNPs in media resulted in the maximum of anthocyanin content in the hairy roots about 4 times higher than that of the control.

\section{Effect of magnetic nanoparticles and salicylic acid on PAL and PPO}

PAL and PPO activity was positively affected by MNPs and the application of SA with MNPs or SA alone in seedlings and hairy roots. For instance, activity of PAL increased by $672,726.2$ and $669 \%$ following exposure of seedlings to $200 \mathrm{mg} \mathrm{L}^{-1} \mathrm{MNPs} 0.1 \mathrm{mM}$ SA and $200 \mathrm{mg} \mathrm{L}^{-1}$ MNPs with $0.1 \mathrm{mM} \mathrm{SA}$, respectively (Fig. 4A). Likewise, MNPs treatment alone showed a positive effect on PAL in 
hairy roots, but a reduction was observed when combined with SA. However, the observed decreases of activity with these values were still significantly higher than the untreated control (Fig. 4B).

The other results of this research include the increase of PPO activity in seedlings and hairy roots under all treatments, with the exception of the foliar application of 50 and $100 \mathrm{mg} \mathrm{L}^{-1}$ MNPs in seedlings (Fig. 4C-D). As compared to control samples, the highest concentration of MNPs combined with the highest concentration of SA increased PPO activity by $42.76 \%$ and $650.2 \%$ in seedlings and hairy roots, respectively.

\section{Effect of magnetic nanoparticles and salicylic acid on FRAP and DPPH}

Significant differences were shown for FRAP and DPPH among different levels of individual and combined treatment of MNPs and SA in Figure3. DPPH level in seedlings was positively changed by MNPs treatments, so that increased up to $81 \%$ of the control at 200 $\mathrm{mg} \mathrm{L}^{-1}$ MNPs (Fig. 5A). DPPH level also showed an increase under SA treatment alone or with MNPs. Respect to the control, the highest level was obtained at $0.05 \mathrm{mM}$ SA with foliar application of $50 \mathrm{mg} \mathrm{L}^{-1} \mathrm{MNPs}$ from 12.9 to $91.8 \%$. Although, the results showed a reduction in the DPPH value for the other treatments of SA alone or with MNPs, those amounts were still higher than those of the control. Similarly, DPPH level in hairy roots highly increased in relation to the severity of MNPs (Fig. 5B). DPPH content increased by 76.6 and $77.3 \%$ in $200 \mathrm{mg} \mathrm{L}^{-1}$, following exposure of roots to MNPs alone or in combination with $0.01 \mathrm{mM} \mathrm{SA}$, respectively.

FRAP level showed a different response to MNPs treatment in seedlings and hairy roots, so that increased at $200 \mathrm{mg} \mathrm{L}^{-1}$ from 46 to $57 \%$ in seedlings and reduced from 48 to $10.37 \%$ in hairy roots (Fig. 5C-D). SA treatment alone had no positive effect on FRAP level in seedlings but was effective in hairy roots. The maximum FRAP value was found at $200 \mathrm{mg} \mathrm{L}^{-1} \mathrm{MNPs}$ and the high concentration of SA in both seedlings and hairy roots, about 1.7 times higher than that of the control.

\section{Effect of magnetic nanoparticles and salicylic acid on essential oil components}

In the study of the effects of the MNPs and SA on oil compositions of hairy roots and seedlings of $C$. procera, 43 compounds were identified (Table 1 and 2). Terpenes make up the major components of the oil; of those, the most important ones were a-terpineol, alpha-pinene, camphor, alpha-thujone, p-cymene, linalool, geranial, germacrene $D$, and $\beta$-ocymene. Data presented in Table 1 reveal that relative to the control, the supplementation of hairy roots media with $100 \mathrm{mg} \mathrm{L}^{-1} \mathrm{MNPs}$ and $0.01 \mathrm{mM} \mathrm{SA}$ generally increased the amount of a-terpineol (31.2\%), alpha-pinene (6.9\%), camphor (11\%) and p-cymene (9.5\%). The content of linalool and germacrene D were increased to a level 2 times higher than that of the control by $200 \mathrm{mg} \mathrm{L}^{-1} \mathrm{MNPs}$ with SA. Furthermore, camphene, limonene, carvacrol, octanol, decanal, myrtenal, cis-pulegone oxide, borneol, thymoquinone, and alpha- longipinene were only detected in hairy roots. Among these aroma constituents of $C$. procera, camphene and carvacrol were increased by about $73 \%$ under $200 \mathrm{mg} \mathrm{L}^{-1}$ MNPs and $0.01 \mathrm{mM} \mathrm{SA}$, in comparison to controls; while limonene and decanal were decreased by 54 and $48.7 \%$, respectively. In contrast with the untreated cultures, the content of octanol was increased by $75 \%$ and that of borneol was raised by $42.8 \%$ at $100 \mathrm{mg}$ $\mathrm{L}^{-1} \mathrm{MNPs}$ and $0.01 \mathrm{mM}$ SA. 
Table 1

Constituents of hairy roots essential oils of $C$. procera treated with synthesized magnetic nanoparticles and salicylic acid using $\mathrm{GC} / \mathrm{MS}$

\begin{tabular}{|c|c|c|c|c|c|c|c|c|}
\hline $\begin{array}{l}\text { Essential oil } \\
\text { components }\end{array}$ & Number & $\begin{array}{l}\text { Retention } \\
\text { Time } \\
\text { (min) }\end{array}$ & Control & $\begin{array}{l}0.01 \mathrm{mM} \\
\mathrm{SA}\end{array}$ & $\begin{array}{l}100 \mathrm{mg} \\
\mathrm{L}^{-1} \\
\text { MNPs }\end{array}$ & $\begin{array}{l}200 \mathrm{mg} \\
\mathrm{L}^{-1} \\
\mathrm{MNPs}\end{array}$ & $\begin{array}{l}100 \mathrm{mg} \mathrm{L}^{-1} \\
\text { MNPs }+0.01 \mathrm{mM} \\
\text { SA }\end{array}$ & $\begin{array}{l}200 \mathrm{mg} \mathrm{L}^{-1} \\
\text { MNPs }+0.01 \mathrm{mM} \\
\text { SA }\end{array}$ \\
\hline Tricyclene & 1 & 1024 & $1.5^{\mathrm{a}}$ & $1.0^{d}$ & $1.2^{b}$ & $1.1^{\mathrm{c}}$ & $0.9^{e}$ & $1.2^{\mathrm{b}}$ \\
\hline alpha-pinene & 2 & 1036 & $2.9^{c}$ & $3.0^{\mathrm{b}}$ & $2.8^{d}$ & $2.6^{\mathrm{e}}$ & $3.1^{\mathrm{a}}$ & $2.6^{\mathrm{e}}$ \\
\hline Alpha-thujone & 3 & 1043 & $2.3^{b}$ & $2.0^{\mathrm{d}}$ & $1.9^{\mathrm{e}}$ & $2.1^{\mathrm{c}}$ & $2.4^{\mathrm{a}}$ & $2.0^{d}$ \\
\hline camphene & 4 & 1100 & $5.1^{f}$ & $5.4^{e}$ & $6.1^{d}$ & $6.9^{c}$ & $7.9^{b}$ & $8.8^{\mathrm{a}}$ \\
\hline Sabinene & 5 & 1133 & $1.9^{f}$ & $2.1^{d}$ & $2.5^{\mathrm{b}}$ & $2.0^{\mathrm{e}}$ & $2.6^{\mathrm{a}}$ & $2.2^{c}$ \\
\hline myrcene & 6 & 1147 & $2.7^{\mathrm{C}}$ & $2.9^{b}$ & $3.1^{\mathrm{a}}$ & $2.6^{d}$ & $1.9^{f}$ & $2.4^{\mathrm{e}}$ \\
\hline A-phellandrene & 7 & 1176 & $1.7^{f}$ & $2.0^{\mathrm{e}}$ & $2.6^{d}$ & $3.4^{\mathrm{C}}$ & $4.1^{b}$ & $5.0^{\mathrm{a}}$ \\
\hline alpha-terpinen & 8 & 1197 & $1.8^{\mathrm{c}}$ & $1.5^{\mathrm{e}}$ & $1.9^{b}$ & $2.1^{\mathrm{a}}$ & $1.8^{\mathrm{c}}$ & $1.6^{d}$ \\
\hline 1,8-Cineol & 9 & 1214 & $2.5^{\mathrm{a}}$ & $2.0^{d}$ & $2.2^{b}$ & $2.0^{d}$ & $1.6^{\mathrm{e}}$ & $2.1^{\mathrm{c}}$ \\
\hline 3-Hexanal & 10 & 1229 & $1.9^{f}$ & $2.5^{\mathrm{a}}$ & $2.1^{\mathrm{d}}$ & $2.2^{\mathrm{c}}$ & $2.3^{b}$ & $2.0^{\mathrm{e}}$ \\
\hline 2-pentyl furan & 11 & 1240 & $1.6^{\mathrm{b}}$ & $1.4^{\mathrm{d}}$ & $1.7^{\mathrm{a}}$ & $1.5^{\mathrm{c}}$ & $1.7^{\mathrm{a}}$ & $1.3^{\mathrm{e}}$ \\
\hline$\beta$-Ocymene & 12 & 1251 & $1.4^{\mathrm{e}}$ & $1.7^{b}$ & $1.5^{\mathrm{d}}$ & $1.6^{\mathrm{c}}$ & $1.8^{\mathrm{a}}$ & $1.5^{\mathrm{d}}$ \\
\hline Limonene & 13 & 1266 & $7.9^{a}$ & $7.7^{b}$ & $6.8^{c}$ & $5.7^{d}$ & $4.6^{\mathrm{e}}$ & $3.6^{f}$ \\
\hline p-Cymene & 14 & 1280 & $2.1^{\mathrm{b}}$ & $1.9^{d}$ & $1.7^{\mathrm{e}}$ & $2.0^{c}$ & $2.3^{a}$ & $1.9^{d}$ \\
\hline $\begin{array}{l}\text { Alpha- } \\
\text { Terpinolene }\end{array}$ & 15 & 1291 & $1.3^{\mathrm{e}}$ & $1.1^{\mathrm{f}}$ & $1.6^{\mathrm{d}}$ & $1.7^{\mathrm{C}}$ & $1.9^{b}$ & $2.1^{\mathrm{a}}$ \\
\hline octanol & 16 & 1320 & $0.8^{f}$ & $1.0^{\mathrm{d}}$ & $0.9^{e}$ & $1.1^{\mathrm{c}}$ & $1.4^{\mathrm{a}}$ & $1.2^{b}$ \\
\hline Cinnamene & 17 & 1346 & $2.5^{\mathrm{a}}$ & $2.2^{\mathrm{b}}$ & $1.8^{\mathrm{d}}$ & $2.2^{\mathrm{b}}$ & $2.0^{c}$ & $1.8^{d}$ \\
\hline myrtenal & 18 & 1384 & $1.9^{a}$ & $1.6^{\mathrm{d}}$ & $1.7^{\mathrm{c}}$ & $1.8^{\mathrm{b}}$ & $1.6^{d}$ & $1.4^{\mathrm{e}}$ \\
\hline Nonanal & 19 & 1408 & $1.1^{\mathrm{e}}$ & $1.4^{\mathrm{c}}$ & $1.3^{d}$ & $1.5^{\mathrm{b}}$ & $1.3^{d}$ & $1.6^{\mathrm{a}}$ \\
\hline $\begin{array}{l}\text { cis-pulegone } \\
\text { oxide }\end{array}$ & 20 & 1425 & $2.3^{b}$ & $2.5^{\mathrm{a}}$ & $2.1^{\mathrm{d}}$ & $1.9^{\mathrm{e}}$ & $2.4^{\mathrm{c}}$ & $1.6^{f}$ \\
\hline $\begin{array}{l}\text { Trans linalool } \\
\text { oxide }\end{array}$ & 21 & 1456 & $2.7^{a}$ & $2.4^{\mathrm{b}}$ & $1.6^{f}$ & $2.1^{\mathrm{c}}$ & $2.0^{d}$ & $1.7^{\mathrm{e}}$ \\
\hline Citronellal & 22 & 1487 & $1.9^{a}$ & $1.6^{\mathrm{d}}$ & $1.7^{\mathrm{c}}$ & $1.5^{\mathrm{e}}$ & $1.8^{\mathrm{b}}$ & $1.4^{f}$ \\
\hline a-Ocapaen & 23 & 1498 & $1.2^{\mathrm{e}}$ & $1.3^{\mathrm{d}}$ & $1.4^{\mathrm{c}}$ & $1.6^{\mathrm{b}}$ & $1.4^{c}$ & $1.8^{\mathrm{a}}$ \\
\hline Camphor & 24 & 1536 & $1.8^{\mathrm{c}}$ & $2.0^{\mathrm{a}}$ & $1.6^{\mathrm{d}}$ & $1.9^{\mathrm{b}}$ & $2.0^{\mathrm{a}}$ & $1.6^{d}$ \\
\hline Linalool & 25 & 1582 & $4.0^{f}$ & $4.3^{\mathrm{e}}$ & $5.3^{d}$ & $6.4^{c}$ & $7.5^{\mathrm{b}}$ & $8.6^{a}$ \\
\hline borneol & 26 & 1596 & $1.4^{f}$ & $1.6^{\mathrm{d}}$ & $1.8^{\mathrm{b}}$ & $1.5^{\mathrm{e}}$ & $2.0^{\mathrm{a}}$ & $1.7^{\mathrm{c}}$ \\
\hline
\end{tabular}

* Values represent the mean of three replicates and dissimilar letters are significantly different according to Duncan's test $(P \leq$ $0.05)$ 


\begin{tabular}{|c|c|c|c|c|c|c|c|c|}
\hline $\begin{array}{l}\text { Essential oil } \\
\text { components }\end{array}$ & Number & $\begin{array}{l}\text { Retention } \\
\text { Time } \\
\text { (min) }\end{array}$ & Control & $\begin{array}{l}0.01 \mathrm{mM} \\
\mathrm{SA}\end{array}$ & $\begin{array}{l}100 \mathrm{mg} \\
\mathrm{L}^{-1} \\
\text { MNPs }\end{array}$ & $\begin{array}{l}200 \mathrm{mg} \\
\mathrm{L}^{-1} \\
\text { MNPs }\end{array}$ & $\begin{array}{l}100 \mathrm{mg} \mathrm{L}^{-1} \\
\text { MNPs }+0.01 \mathrm{mM} \\
\text { SA }\end{array}$ & $\begin{array}{l}200 \mathrm{mg} \mathrm{L}^{-1} \\
\text { MNPs }+0.01 \mathrm{mM} \\
\text { SA }\end{array}$ \\
\hline Bornyl acetate & 27 & 1606 & $1.9^{d}$ & $2.1^{\mathrm{b}}$ & $2.0^{c}$ & $2.1^{\mathrm{b}}$ & $1.7^{\mathrm{e}}$ & $2.2^{\mathrm{a}}$ \\
\hline Terpinen-4-ol & 28 & 1618 & $1.8^{\mathrm{d}}$ & $2.0^{\mathrm{b}}$ & $2.2^{\mathrm{a}}$ & $1.9^{\mathrm{c}}$ & $1.6^{\mathrm{e}}$ & $1.8^{d}$ \\
\hline Thymoquinone & 29 & 1637 & $5.9^{\mathrm{a}}$ & $5.6^{\mathrm{b}}$ & $4.8^{\mathrm{C}}$ & $3.7^{d}$ & $2.8^{\mathrm{e}}$ & $1.9^{f}$ \\
\hline carvacrol & 30 & 1660 & $1.5^{f}$ & $2.3^{b}$ & $2.1^{\mathrm{c}}$ & $2.0^{d}$ & $1.8^{\mathrm{e}}$ & $2.6^{\mathrm{a}}$ \\
\hline $\begin{array}{l}\text { Citronellyl } \\
\text { acetate }\end{array}$ & 31 & 1677 & $1.3^{\mathrm{e}}$ & $1.5^{\mathrm{c}}$ & $1.6^{\mathrm{b}}$ & $1.5^{\mathrm{c}}$ & $1.8^{\mathrm{a}}$ & $1.4^{\mathrm{d}}$ \\
\hline decanal & 32 & 1696 & $8.0^{\mathrm{a}}$ & $7.8^{\mathrm{b}}$ & $6.9^{c}$ & $5.8^{d}$ & $4.9^{e}$ & $4.1^{f}$ \\
\hline Benzaldehyde & 33 & 1716 & $2.2^{\mathrm{a}}$ & $1.9^{\mathrm{c}}$ & $2.0^{\mathrm{b}}$ & $1.8^{\mathrm{d}}$ & $1.6^{\mathrm{e}}$ & $1.4^{f}$ \\
\hline Geranial & 34 & 1741 & $2.0^{\mathrm{b}}$ & $2.1^{\mathrm{a}}$ & $1.8^{\mathrm{d}}$ & $1.2^{f}$ & $1.4^{\mathrm{e}}$ & $1.9^{\mathrm{c}}$ \\
\hline Citronellol & 35 & 1772 & $1.4^{\mathrm{e}}$ & $1.6^{\mathrm{C}}$ & $1.7^{\mathrm{b}}$ & $1.9^{a}$ & $1.5^{\mathrm{d}}$ & $1.7^{b}$ \\
\hline a-Terpineol & 36 & 1790 & $1.6^{d}$ & $2.0^{\mathrm{b}}$ & $1.8^{\mathrm{c}}$ & $1.6^{\mathrm{d}}$ & $2.1^{\mathrm{a}}$ & $2.0^{\mathrm{b}}$ \\
\hline Benzyl acetate & 37 & 1869 & $1.8^{\mathrm{b}}$ & $1.5^{\mathrm{d}}$ & $2.0^{\mathrm{a}}$ & $1.3^{f}$ & $1.4^{\mathrm{e}}$ & $1.6^{c}$ \\
\hline $\begin{array}{l}\text { alpha- } \\
\text { longipinene }\end{array}$ & 38 & 1921 & $0.7^{\mathrm{e}}$ & $0.9^{d}$ & $11.1^{\mathrm{a}}$ & $1.2^{\mathrm{c}}$ & $0.9^{d}$ & $1.3^{\mathrm{b}}$ \\
\hline Methyl Eugenol & 39 & 2016 & $1.9^{\mathrm{c}}$ & $2.2^{\mathrm{a}}$ & $2.0^{\mathrm{b}}$ & $1.7^{d}$ & $1.5^{\mathrm{e}}$ & $1.2^{f}$ \\
\hline $\begin{array}{l}\text { Humulene } \\
\text { epoxide }\end{array}$ & 40 & 2033 & $1.2^{\mathrm{d}}$ & $1.4^{\mathrm{b}}$ & $1.3^{\mathrm{c}}$ & $1.1^{\mathrm{e}}$ & $1.4^{\mathrm{b}}$ & $1.6^{\mathrm{a}}$ \\
\hline Germacrene D & 41 & 2069 & $3.5^{f}$ & $3.9^{\mathrm{e}}$ & $4.6^{d}$ & $5.5^{c}$ & $6.6^{\mathrm{b}}$ & $7.8^{\mathrm{a}}$ \\
\hline $\begin{array}{l}\text { Phenyl } \\
\text { acetaldehyde }\end{array}$ & 42 & 2226 & $1.0^{c}$ & $0.8^{\mathrm{e}}$ & $0.9^{d}$ & $1.1^{\mathrm{b}}$ & $1.0^{\mathrm{C}}$ & $1.2^{\mathrm{a}}$ \\
\hline Cubenol & 43 & 2259 & $1.3^{\mathrm{b}}$ & $1.1^{\mathrm{d}}$ & $1.2^{\mathrm{c}}$ & $1.4^{\mathrm{a}}$ & $1.3^{\mathrm{b}}$ & $1.0^{\mathrm{e}}$ \\
\hline
\end{tabular}


Table 2

Constituents of leaf essential oils of $C$. procera treated with synthesized magnetic nanoparticles and salicylic acid using GC/MS

\begin{tabular}{|c|c|c|c|c|c|c|c|c|c|c|c|}
\hline $\begin{array}{l}\text { Essential oil } \\
\text { components }\end{array}$ & Num. & RT & Control & $\begin{array}{l}100 \\
\mathrm{mg} \\
\mathrm{L}^{-1} \\
\text { MNPs }\end{array}$ & $\begin{array}{l}200 \\
\mathrm{mg} \\
\mathrm{L}^{-1} \\
\text { MNPs }\end{array}$ & $\begin{array}{l}0.05 \mathrm{mM} \\
\mathrm{SA}\end{array}$ & $\begin{array}{l}0.1 \\
\mathrm{mM} \\
\mathrm{SA}\end{array}$ & $\begin{array}{l}100 \mathrm{mg} \\
\mathrm{L}^{-1} \\
\mathrm{MNPs}+ \\
0.05 \mathrm{mM} \\
\mathrm{SA}\end{array}$ & $\begin{array}{l}200 \mathrm{mg} \\
\mathrm{L}^{-1} \\
\mathrm{MNPs}+ \\
0.05 \mathrm{mM} \\
\mathrm{SA}\end{array}$ & $\begin{array}{l}100 \\
\mathrm{mg} \mathrm{L}^{-1} \\
\text { MNPs } \\
+ \\
0.1 \mathrm{mM} \\
\text { SA }\end{array}$ & $\begin{array}{l}200 \\
\mathrm{mg} \mathrm{L}^{-1} \\
\text { MNPs } \\
+ \\
0.1 \mathrm{mM} \\
\mathrm{SA}\end{array}$ \\
\hline Tricyclene & 1 & 1024 & $2.9^{a}$ & $2.4^{b}$ & $2.1^{\mathrm{e}}$ & $2.3^{\mathrm{c}}$ & $1.4^{\mathrm{i}}$ & $2.2^{d}$ & $1.7^{\mathrm{g}}$ & $2.0^{f}$ & $1.6^{\mathrm{h}}$ \\
\hline alpha-pinene & 2 & 1036 & $1.5^{\mathrm{i}}$ & $2.2^{f}$ & $3.0^{\mathrm{e}}$ & $2.0^{\mathrm{g}}$ & $1.8^{\mathrm{h}}$ & $3.3^{d}$ & $5.1^{\mathrm{b}}$ & $3.8^{\mathrm{c}}$ & $5.8^{\mathrm{a}}$ \\
\hline Alpha-thujone & 3 & 1043 & $2.0^{c}$ & $2.0^{c}$ & $2.2^{\mathrm{b}}$ & $3.4^{\mathrm{a}}$ & $2.0^{c}$ & $1.7^{d}$ & $1.6^{\mathrm{e}}$ & $1.5^{f}$ & $1.5^{f}$ \\
\hline Undecene & 4 & 1100 & $2.4^{\mathrm{c}}$ & $2.5^{b}$ & $2.4^{\mathrm{c}}$ & $3.1^{\mathrm{a}}$ & $2.5^{\mathrm{b}}$ & $2.5^{\mathrm{b}}$ & $2.2^{d}$ & $2.2^{d}$ & $2.0^{\mathrm{e}}$ \\
\hline Sabinene & 5 & 1133 & $3.1^{\mathrm{b}}$ & $1.9^{h}$ & $2.2^{f}$ & $2.7^{\mathrm{c}}$ & $3.2^{\mathrm{a}}$ & $2.4^{\mathrm{e}}$ & $2.1^{\mathrm{g}}$ & $2.5^{\mathrm{d}}$ & $2.2^{f}$ \\
\hline$\delta$-2-Carene & 6 & 1147 & $2.0^{e}$ & $1.6^{\mathrm{h}}$ & $1.7^{\mathrm{g}}$ & $3.4^{\mathrm{a}}$ & $2.3^{\mathrm{c}}$ & $2.2^{\mathrm{d}}$ & $2.5^{\mathrm{b}}$ & $1.9^{f}$ & $1.5^{\mathrm{i}}$ \\
\hline A-phellandrene & 7 & 1176 & $1.3^{\mathrm{i}}$ & $2.9^{f}$ & $3.6^{d}$ & $1.6^{\mathrm{h}}$ & $2.4^{\mathrm{g}}$ & $3.5^{\mathrm{e}}$ & $5.3^{b}$ & $4.1^{\mathrm{c}}$ & $6.6^{\mathrm{a}}$ \\
\hline 3-Hexanol & 8 & 1197 & $2.1^{d}$ & $1.7^{f}$ & $1.9^{\mathrm{e}}$ & $2.5^{\mathrm{a}}$ & 1.7 & $2.4^{\mathrm{b}}$ & $2.3^{\mathrm{c}}$ & $1.6^{\mathrm{g}}$ & $2.3^{\mathrm{c}}$ \\
\hline 1,8-Cineol & 9 & 1214 & $1.2^{\mathrm{i}}$ & $3.4^{f}$ & $5.1^{\mathrm{c}}$ & $1.7^{\mathrm{h}}$ & $2.6^{\mathrm{g}}$ & $3.6^{\mathrm{e}}$ & $6.0^{\mathrm{b}}$ & $4.4^{\mathrm{d}}$ & $7.0^{\mathrm{a}}$ \\
\hline 3-Hexanal & 10 & 1229 & $2.6^{\mathrm{c}}$ & $2.2^{f}$ & $2.5^{\mathrm{d}}$ & $2.8^{\mathrm{b}}$ & $2.0^{\mathrm{g}}$ & $3.0^{\mathrm{a}}$ & $2.4^{\mathrm{e}}$ & $2.6^{\mathrm{C}}$ & $2.4^{\mathrm{e}}$ \\
\hline 2-pentyl furan & 11 & 1240 & $3.4^{\mathrm{a}}$ & $2.6^{\mathrm{c}}$ & $2.3^{f}$ & $2.5^{\mathrm{d}}$ & $2.2^{\mathrm{g}}$ & $2.8^{\mathrm{b}}$ & $2.1^{\mathrm{h}}$ & $2.4^{\mathrm{e}}$ & $2.1^{\mathrm{h}}$ \\
\hline$\beta$-Ocymene & 12 & 1251 & $2.8^{\mathrm{b}}$ & $1.8^{f}$ & $2.0^{\mathrm{e}}$ & $2.7^{c}$ & $2.9^{a}$ & $2.5^{\mathrm{d}}$ & $1.8^{f}$ & $2.0^{e}$ & $1.7^{\mathrm{g}}$ \\
\hline p-Cymene & 13 & 1280 & $1.9^{c}$ & $1.5^{f}$ & $1.7^{\mathrm{e}}$ & $2.4^{\mathrm{a}}$ & $1.8^{\mathrm{d}}$ & $1.8^{\mathrm{d}}$ & $2.0^{\mathrm{b}}$ & $1 .^{f}$ & $2.0^{\mathrm{b}}$ \\
\hline Alpha-Terpinolene & 14 & 1291 & $3.7^{\mathrm{a}}$ & $3.4^{\mathrm{c}}$ & $2.9^{d}$ & $2.1^{f}$ & $3.5^{\mathrm{b}}$ & $2.3^{\mathrm{e}}$ & $1.7^{\mathrm{g}}$ & $2.1^{f}$ & $1.7^{\mathrm{g}}$ \\
\hline Heptanal & 15 & 1311 & $3.3^{\mathrm{a}}$ & $3.1^{b}$ & $2.6^{\mathrm{c}}$ & $2.0^{g}$ & $3.1^{\mathrm{b}}$ & $2.0^{\mathrm{g}}$ & $2.2^{\mathrm{e}}$ & $2.5^{\mathrm{d}}$ & $2.1^{f}$ \\
\hline Cinnamene & 16 & 1346 & $1.9^{\mathrm{c}}$ & $1.4^{\mathrm{g}}$ & $1.4^{\mathrm{g}}$ & $2.4^{\mathrm{b}}$ & $3.2^{\mathrm{a}}$ & $1.7^{\mathrm{e}}$ & $1.8^{\mathrm{d}}$ & $1.9^{\mathrm{c}}$ & $1.6^{f}$ \\
\hline Pelargonaldehyde & 17 & 1389 & $2.7^{\mathrm{b}}$ & $2.9^{a}$ & $2.7^{\mathrm{b}}$ & $1.9^{\mathrm{g}}$ & $2.9^{a}$ & $2.5^{\mathrm{c}}$ & $2.0^{f}$ & $2.2^{\mathrm{d}}$ & $2.1^{\mathrm{e}}$ \\
\hline Nonanal & 18 & 1408 & $1.9^{d}$ & $2.5^{\mathrm{a}}$ & $2.2^{b}$ & $2.2^{\mathrm{b}}$ & $2.0^{c}$ & $2.2^{b}$ & $1.7^{f}$ & $1.8^{\mathrm{e}}$ & $1.8^{\mathrm{e}}$ \\
\hline Fenchone & 19 & 1417 & $3.4^{\mathrm{a}}$ & $1.8^{\mathrm{h}}$ & $2.1^{\mathrm{e}}$ & $2.0^{f}$ & $3.1^{\mathrm{b}}$ & $1.9^{g}$ & $2.4^{\mathrm{C}}$ & $2.3^{d}$ & $2.4^{\mathrm{c}}$ \\
\hline $\begin{array}{l}\text { Trans linalool } \\
\text { oxide }\end{array}$ & 20 & 1456 & $1.8^{f}$ & $2.5^{\mathrm{b}}$ & $2.4^{\mathrm{C}}$ & $2.9^{a}$ & $1.7^{\mathrm{g}}$ & $2.1^{d}$ & $1.8^{f}$ & $1.9^{\mathrm{e}}$ & $1.6^{\mathrm{h}}$ \\
\hline Citronellal & 21 & 1487 & $1.4^{f}$ & $4.0^{d}$ & $2.1^{\mathrm{e}}$ & $1.3^{\mathrm{g}}$ & $1.2^{\mathrm{h}}$ & $6.2^{\mathrm{b}}$ & $4.6^{c}$ & $6.6^{\mathrm{a}}$ & $4.6^{c}$ \\
\hline a-Ocapaen & 22 & 1498 & $2.2^{\mathrm{b}}$ & $1.7^{\mathrm{d}}$ & $2.0^{c}$ & $3.1^{\mathrm{a}}$ & $2.0^{c}$ & $2.0^{c}$ & $1.6^{\mathrm{e}}$ & $1.6^{\mathrm{e}}$ & $1.4^{f}$ \\
\hline Camphor & 23 & 1536 & $1.2^{\mathrm{g}}$ & $4.3^{c}$ & $2.0^{f}$ & $1.1^{\mathrm{h}}$ & $1.2^{\mathrm{g}}$ & $4.7^{b}$ & $2.2^{\mathrm{e}}$ & $5.9^{a}$ & $2.6^{d}$ \\
\hline Linalool & 24 & 1582 & $2.6^{d}$ & $2.4^{f}$ & $3.1^{\mathrm{c}}$ & $3.2^{\mathrm{b}}$ & $3.7^{a}$ & $2.4^{f}$ & $2.5^{\mathrm{e}}$ & $2.0^{\mathrm{g}}$ & $2.5^{\mathrm{e}}$ \\
\hline Carbaldehyde & 25 & 1594 & $2.8^{\mathrm{b}}$ & $2.5^{d}$ & $2.8^{\mathrm{b}}$ & $2.6^{\mathrm{C}}$ & $3.0^{\mathrm{a}}$ & $2.2^{\mathrm{e}}$ & $2.0^{f}$ & $2.2^{\mathrm{e}}$ & $2.0^{f}$ \\
\hline Bornyl acetate & 26 & 1606 & $2.5^{\mathrm{c}}$ & $2.2^{d}$ & $2.6^{\mathrm{b}}$ & $2.0^{\mathrm{e}}$ & $3.3^{\mathrm{a}}$ & $1.8^{f}$ & $1.7^{\mathrm{g}}$ & $1.7^{\mathrm{g}}$ & $1.6^{\mathrm{h}}$ \\
\hline
\end{tabular}

* Values represent the mean of three replicates and dissimilar letters are significantly different according to Duncan's test $(P \leq$ $0.05)$ 


\begin{tabular}{|c|c|c|c|c|c|c|c|c|c|c|c|}
\hline $\begin{array}{l}\text { Essential oil } \\
\text { components }\end{array}$ & Num. & RT & Control & $\begin{array}{l}100 \\
\mathrm{mg} \\
\mathrm{L}^{-1} \\
\text { MNPs }\end{array}$ & $\begin{array}{l}200 \\
\mathrm{mg} \\
\mathrm{L}^{-1} \\
\text { MNPs }\end{array}$ & $\begin{array}{l}0.05 \mathrm{mM} \\
\text { SA }\end{array}$ & $\begin{array}{l}0.1 \\
\mathrm{mM} \\
\mathrm{SA}\end{array}$ & $\begin{array}{l}100 \mathrm{mg} \\
\mathrm{L}^{-1} \\
\mathrm{MNPs}+ \\
0.05 \mathrm{mM} \\
\mathrm{SA}\end{array}$ & $\begin{array}{l}200 \mathrm{mg} \\
\mathrm{L}^{-1} \\
\text { MNPs + } \\
0.05 \mathrm{mM} \\
\text { SA }\end{array}$ & $\begin{array}{l}100 \\
\mathrm{mg} \mathrm{L}^{-1} \\
\mathrm{MNPs} \\
+ \\
0.1 \mathrm{mM} \\
\text { SA }\end{array}$ & $\begin{array}{l}200 \\
\mathrm{mg} \mathrm{L}^{-1} \\
\text { MNPs } \\
+ \\
0.1 \mathrm{mM} \\
\text { SA }\end{array}$ \\
\hline Terpinen-4-ol & 27 & 1618 & $1.2^{\mathrm{i}}$ & $4.6^{c}$ & $2.3^{d}$ & $1.3^{\mathrm{h}}$ & $1.4^{\mathrm{g}}$ & $4.8^{\mathrm{a}}$ & $2.0^{e}$ & $4.7^{b}$ & $1.8^{f}$ \\
\hline a-Furole & 28 & 1647 & $1.6^{\mathrm{e}}$ & $1.6^{\mathrm{e}}$ & $2.4^{\mathrm{b}}$ & $1.9^{d}$ & $2.7^{\mathrm{a}}$ & $1.4^{\mathrm{g}}$ & $2.3^{\mathrm{c}}$ & $1.5^{f}$ & $2.3^{\mathrm{c}}$ \\
\hline 1-Nonanol & 29 & 1663 & $3.3^{b}$ & $2.4^{\mathrm{d}}$ & $2.2^{\mathrm{e}}$ & $3.5^{\mathrm{a}}$ & $3.0^{c}$ & $1.2^{\mathrm{i}}$ & $1.6^{\mathrm{g}}$ & $1.9^{f}$ & $1.5^{\mathrm{h}}$ \\
\hline Citronellyl acetate & 30 & 1677 & $2.6^{\mathrm{b}}$ & $1.3^{\mathrm{e}}$ & $2.0^{c}$ & $2.6^{\mathrm{b}}$ & $2.8^{\mathrm{a}}$ & 1.1 & $2.0^{\mathrm{C}}$ & $1.4^{\mathrm{d}}$ & $2.0^{c}$ \\
\hline Hotrienol & 31 & 1690 & $1.6^{\mathrm{d}}$ & $1.1^{\mathrm{e}}$ & $1.7^{\mathrm{c}}$ & $1.9^{\mathrm{a}}$ & $1.6^{\mathrm{d}}$ & $1.8^{\mathrm{b}}$ & $1.7^{\mathrm{c}}$ & $1.6^{\mathrm{d}}$ & $1.7^{\mathrm{c}}$ \\
\hline Benzaldehyde & 32 & 1716 & $2.8^{\mathrm{a}}$ & $1.9^{d}$ & $2.1^{\mathrm{c}}$ & $1.7^{\mathrm{e}}$ & $2.6^{\mathrm{b}}$ & $1.2^{\mathrm{h}}$ & $1.4^{\mathrm{g}}$ & $1.5^{f}$ & $1.2^{\mathrm{h}}$ \\
\hline Germacrene D & 33 & 1728 & $3.1^{\mathrm{a}}$ & $3.0^{\mathrm{b}}$ & $2.2^{d}$ & $1.9^{f}$ & $2.9^{c}$ & $1.0^{\mathrm{h}}$ & $2.1^{\mathrm{e}}$ & $1.4^{\mathrm{g}}$ & $2.1^{\mathrm{e}}$ \\
\hline Geranial & 34 & 1741 & 1.4 & $3.0^{f}$ & $5.2^{\mathrm{c}}$ & $1.6^{\mathrm{g}}$ & $1.5^{\mathrm{h}}$ & $3.8^{\mathrm{e}}$ & $6.6^{\mathrm{b}}$ & $4.6^{d}$ & $7.7^{\mathrm{a}}$ \\
\hline Citronellol & 35 & 1772 & $3.2^{\mathrm{b}}$ & $1.8^{\mathrm{e}}$ & $1.9^{d}$ & $3.5^{\mathrm{a}}$ & $3.1^{c}$ & $1.9^{d}$ & $1.8^{\mathrm{e}}$ & $1.5^{f}$ & $1.5^{f}$ \\
\hline a-Terpineol & 36 & 1790 & $2.5^{c}$ & $3.1^{\mathrm{a}}$ & $2.0^{d}$ & $2.7^{\mathrm{b}}$ & $2.7^{b}$ & $1.6^{\mathrm{e}}$ & $1.6^{\mathrm{e}}$ & $2.0^{d}$ & $1.5^{f}$ \\
\hline Benzyl acetate & 37 & 1869 & $2.1^{\mathrm{e}}$ & $2.5^{\mathrm{a}}$ & $1.8^{f}$ & $2.1^{\mathrm{e}}$ & $2.4^{\mathrm{b}}$ & $1.8^{f}$ & $2.3^{c}$ & $2.2^{d}$ & $1.3^{\mathrm{g}}$ \\
\hline Ethyl Maltol & 38 & 1919 & $1.8^{\mathrm{d}}$ & $1.2^{\mathrm{g}}$ & $1.6^{f}$ & $2.4^{\mathrm{b}}$ & $2.5^{\mathrm{a}}$ & $1.9^{\mathrm{c}}$ & $1.8^{\mathrm{d}}$ & $1.7^{\mathrm{e}}$ & $1.9^{\mathrm{c}}$ \\
\hline Methyl Eugenol & 39 & 2016 & $2.7^{\mathrm{b}}$ & $2.1^{d}$ & $1.9^{f}$ & $2.9^{a}$ & $2.4^{c}$ & $1.8^{\mathrm{g}}$ & $1.6^{\mathrm{h}}$ & $2.0^{e}$ & $1.5^{\mathrm{i}}$ \\
\hline $\begin{array}{l}\text { Humulene } \\
\text { epoxide }\end{array}$ & 40 & 2033 & $1.6^{\mathrm{C}}$ & $1.3^{\mathrm{e}}$ & $1.3^{\mathrm{e}}$ & $2.6^{\mathrm{a}}$ & $1.7^{b}$ & $1.1^{\mathrm{f}}$ & $1.4^{\mathrm{d}}$ & $1.6^{\mathrm{C}}$ & $1.3^{\mathrm{e}}$ \\
\hline Nerolidol & 41 & 2054 & $2.8^{a}$ & $2.2^{\mathrm{d}}$ & $2.3^{\mathrm{c}}$ & $1.8^{\mathrm{g}}$ & $2.6^{\mathrm{b}}$ & $1.6^{\mathrm{h}}$ & $2.1^{\mathrm{e}}$ & $1.9^{f}$ & $1.1^{\mathrm{i}}$ \\
\hline $\begin{array}{l}\text { Phenyl } \\
\text { acetaldehyde }\end{array}$ & 42 & 2246 & $2.5^{\mathrm{a}}$ & $1.4^{\mathrm{e}}$ & $1.6^{\mathrm{C}}$ & $1.5^{\mathrm{d}}$ & $1.8^{\mathrm{b}}$ & $1.5^{\mathrm{d}}$ & $1.1^{f}$ & $0.8^{\mathrm{h}}$ & $1.0^{\mathrm{g}}$ \\
\hline Cubenol & 43 & 2259 & $1.6^{\mathrm{b}}$ & $1.6^{\mathrm{b}}$ & $1.1^{\mathrm{d}}$ & $1.3^{\mathrm{c}}$ & $0.8^{f}$ & $1.8^{\mathrm{a}}$ & $0.8^{f}$ & $0.9^{e}$ & $1.1^{\mathrm{d}}$ \\
\hline
\end{tabular}

Besides, studying the essential oil components obtained from the plant seedlings revealed that among the treatments tested, SA alone especially concentrations of $0.05 \mathrm{mM} \mathrm{SA}$ had the best effect on these components (Table 2). For instance, $0.05 \mathrm{mM} \mathrm{SA}$ induced a significant increase in alpha-thujone content by $70 \%$, p-cymene by $26 \%$, linalool by $23 \%$, methyl eugenol by $7 \%$, and 1 nonanol by $6 \%$ as compared to the control seedlings. Like hairy roots, camphor is one of the constituents of the $C$. procera that was detected in seedlings and increased by $391.6 \%$ under $100 \mathrm{mg} \mathrm{L}^{-1} \mathrm{MNPs}$ and $0.1 \mathrm{mM}$ SA treatment. Likewise, geranial and alphapinene are other important compounds that increased up to 5.5 and 3.8 times more than the control under $200 \mathrm{mg} \mathrm{L}^{-1} \mathrm{MNPs}$ and 0.1 mM SA treatment, respectively. Moreover, undecene, 8-2-carene, 3-hexanol, heptanal, fenchone, a-furole, hotrienol, ethyl maltol and nerolidol were only observed in seedlings.

\section{Discussions}

This study aimed at provision appropriate platform for fast and cost-effective production of pharmacological metabolites in high quantities and improvement of antioxidant activities of $C$. procera. Here, according to the results, hairy root culture achieved a high attention due to high growth rate in less time, eases of maintenance and affordable nutrition, as compared to seedlings grown under hydroponic condition. There are numerous reports of high potential of hairy root cultures in increasing the production and 
accumulation of high-value specialized plant metabolites of many species (Garagounis et al. 2020; Ghararia et al. 2020). Nonetheless, developing of the successful hairy root transformation in each plant species depends on many factors, such as explants type, cultivar, culture conditions, Agrobacterium strain, inoculation methods and duration of plant tissue-bacterial suspension. In this study, we have successfully established a hairy-root protocol for $C$. procera, as a tool for fast production of a large number of secondary metabolites. Hairy root induction appeared in leaf explants about 10 days post-infection from wounded sites only with strain A4 of $A$. rhizogenes. Besides, a more rapid growth of roots was also obtained after transfer to liquid medium during a month.

Furthermore, in this study, addition of MNPs and SA to the growth medium was emerged as an efficient strategy to induce or enhance synthesis of the secondary metabolites. This study confirmed that the additions of MNPs and SA at the certain concentration could elevate total phenolics, flavonoids, flavonol, and anthocyanin (Fig. 3). Phenolic and flavonoid compounds are the largest group of plant secondary metabolites with antioxidant and antiradical defense activity. These compounds can directly react with reactive oxygen species (ROS) to form stable and relatively nontoxic macromolecular radicals because of hydroxyl groups of their structure (Bendary et al. 2013). In addition, some of them are considered to be liable for stimulation the synthesis of endogenous antioxidant molecules in the cell (Côté et al. 2010). Given their therapeutic perspective, tremendous innovations are underway in the process of discovering phenolic compounds from various plants and improving them. Countless studies reported that phenolic metabolism can be stimulated by different biotic and abiotic stresses (Ahuja et al. 2012; Cesco et al. 2010). Here, for the first time, different concentrations of MNPs and SA were applied in $C$. procera seedlings and hairy roots to increase the production of secondary metabolites such as phenolic, flavonoid, flavonol, and anthocyanin, which in normal conditions are found in plant cells in low levels. The result showed that among all treatments applied, the highest concentration of MNPs $\left(200 \mathrm{mg} \mathrm{L}^{-1}\right)$ along with SA was the most effective to enhance the content of these compounds when compared to the control samples. It has been proposed that the accumulation of these compounds is closely correlated with ROS burst caused in cells by the elicitors.

In addition, the increase of the phenolics seems to be related to the activities of PAL and PPO enzymes (Ghorbanpour and Hadian 2015).In this study, a significant relationship between these enzymes and enhancement of total phenolics biosynthesis following exposure to $200 \mathrm{mg} \mathrm{L}^{-1}$ MNPs with $0.1 \mathrm{mM} \mathrm{SA}$ in both seedlings and hairy roots has been observed (Fig. 4). This study is in agreement with previous report by Tato et al. (2013), who suggested that a rise in PAL activity, a key enzyme in pathway of biosynthesis of phenolic compounds, is correlated with accumulation of total phenolics in Parietaria judaica L. Similarly, significant correlation between the production of phenolic compounds and PAL activity has also been reported in $D$. kotschyi hairy-root by Nourozi group (2019) and in Salvia miltiorrhiza hairy roots by Yan et al. (2006). In other study, alteration of phenolics as a result of the increase PAL activity affected by phytoregulators has been reported as well (Blanch et al. 2020). Like PAL, an increase in PPO activity could also be considered as a marker of plant reaction to adverse environmental conditions. This enzyme plays an important role in oxidation of a great number of phenolic compounds. In Satureja khuzestanica under multi-walled carbon nanotubes treatments (Ghorbanpour and Hadian 2015) and in hazel cell suspension cultures under static magnetic field (SMF) and SMF combined with the salicylic acid treatments (Rezaei et al. 2010) had been reported similar to the present results.

Moreover, a significant correlation between the total phenol content and antioxidant capacity (DPPH scavenging activity, FRAP value) was observed in $C$. procera seedlings and hairy roots affected by MNPs and SA, which indicates most phenolics were the major contributors to the free radical scavenging (Fig. 5). These results are in a good line with previous reports that showed a positive relationship between total flavonoid content and antioxidant activity in Zingiber officinale after foliar application of SA (Ghasemzadeh et al. 2012). Similar trend in phenolic content and antioxidant activity in in soybean (Shokrollahi et al. 2018), Citrus sinensis L. (Huang et al. 2008), and Punica granatum L. (Zhuang et al. 2011) was also reported. Likewise, anthocyanin was shown as another of potent antioxidant compound with high DPPH activity in C. procera that is consistent with other report (Shih et al. 2010). Therefore, these observed strong correlations between these secondary metabolites and antioxidant activity confirm that phenolics, flavonoids, and anthocyanin are the main constituents contributing to the antioxidant activity in C. procera.

Furthermore, in this investigation, it has been demonstrated that MNPs and SA are very potential elicitors for induction the essential oil of the seedlings and hairy roots of $C$. procera. It seems that the MNPs and SA alter essential oils production by stimulating the expression of genes involved in the relevant biosynthetic pathway. Our results indicate that terpenes with a wide range of industrial and medicinal applications are the major constituents of the oils in both seedlings and hairy roots as shown in Tabl 1-2. In this investigation, these components were strongly influenced by MNPs and SA, resulting in significant differences between oils content 
of seedlings and hairy roots. For instance, $100 \mathrm{mg} \mathrm{L}^{-1} \mathrm{MNPs}$ and $0.01 \mathrm{mM} \mathrm{SA}$ treatments induced a significant increase in content of a-terpineol by $110 \%$ in hairy roots, while $100 \mathrm{mg} \mathrm{L}^{-1} \mathrm{MNPs}$ alone increased it up to $24 \%$ in seedlings. Antihypertensive, antiinflammatory and anticancer properties of a-terpineol have already been proven (Khaleel et al. 2018). Likewise, the content of linalool and germacrene $D$ was increased by all treatments applied in hairy roots whereas these treatments decreased germacrene $D$ in seedlings. Previous reports indicated that the increase observed in terpene concentrations under abiotic treatments is correlated with trade-off in carbon skeletons allocation between growth and defense (Razavizadeh et al. 2019). Here, based on previous studies on the potential of Fe-NPs and SA (Mozafari et al. 2018) in increase of photosynthetic pigments, it is proposed that both treatments through motivating photosynthesis processes and subsequent the enhancement of the carbohydrate content may increase the production of secondary metabolites.

Another significant achievement in this research is presence carvacrol, limonene, and camphene with highly potent biological and pharmacological properties in hairy roots. Carvacrol is a monoterpenoid of the phenolic group that have been illustrated in recent studies to have antioxidant, antimicrobial, anti-mutagenic, analgesic, anti-platelet, anti-inflammatory, and anti-tumor activities (Nostro and Papalia 2012). Camphene has shown strong potential in reduction plasma cholesterol and triglycerides in rats with hyperlipidemia (Vallianou et al. 2011). Also, it is reported that limonene can decrease overall stress levels and improve markers of inflammation. Due to the pharmacological importance of these compounds, increasing their content could be valuable. Here, it was shown that $200 \mathrm{mg} \mathrm{L}^{-1} \mathrm{MNPs}$ and $0.01 \mathrm{mM} \mathrm{SA}$ increased carvacrol and camphene by about $73 \%$ in comparison to controls. There are similar reports of an increase in secondary metabolites due to the application of Fe-NPs (Mohasseli et al. 2020) and SA (Mendoza et al. 2018) individually. To the best of our knowledge, there was no report of the combined effects of $\mathrm{Fe}_{3} \mathrm{O}_{4}-\mathrm{MNPs}$ and SA on essential oil components till date. Our results suggest that MNPs combined with the SA treatment would be very beneficial in stimulating production of phenolics compounds, flavonoids and main essential oils $C$. procera. However, the exact involved mechanisms are not yet completely unraveled and transcriptomic and proteomic studies of defense genes and proteins are need to view to fully understand about modulation effects of these treatments.

In conclusion, this experiment provides the first report on the optimized use of synthesized magnetic nanoparticles combined with the salicylic acid to enhance the biosynthesis of pharmaceutical metabolites including phenolics compounds, flavonoids and main essential oils in $C$. procera seedlings and hairy roots. Hairy root culture is recommended as more efficient alternative for the higher production of the secondary metabolites and improving pharmacological constituents, especially when the media is supplemented to MNPs and SA. Despite almost similar antioxidant responses and main components of essential oil in seedlings and hairy roots, faster growth of hairy roots that reduces the process time to attain high product concentrations and the presence of special compounds such as carvacrol and camphene corroborate the effectiveness of the proposed hairy root culture relative to seedlings. Regarding the highest content of secondary metabolites and medicinal constituents, we suggest that the use of 100 and $200 \mathrm{mg} \mathrm{L}^{-1}$ MNPs combined with $0.01 \mathrm{mM} \mathrm{SA}$ in hairy root culture is a promising tool for improvement of valuable antioxidant compounds of $C$. procera.

\section{Abbreviations}

AICl3: Aluminum chloride; DPPH: 2,2-diphenyl-1-picrylhydrazyl; FRAP: Ferric-reducing antioxidant power; GC/MS: Gas chromatography-mass spectrometry; LB: Luria-Bertani; MNPs: Magnetic nanoparticles; MS: Murashige and Skoog nutrient medium; NPs: Nanoparticles; PAL: L-phenylalanine ammonia-lyase; PPO: Polyphenol oxidase; SA: Salicylic acid, ROS: reactive oxygen species

\section{Declarations}

Acknowledgments This study was supported by Shahid Bahonar University of Kerman, Iran.

Author contributions All authors contributed to the study conception and design. FA Investigation, Data curation, Formal analysis, Writing - original draft, Writing - review and editing. ShP Design of the study, Writing - review and editing. NN Project administration, Writing - review and editing. RR Supervision, Writing - review and editing. HM Writing - review and editing. All authors read and approved final version of manuscript. 
Data availability All data generated or analyzed during this study are included in this published article (and its supplementary information files).

Conflict of interest The authors declare that they have no conflict of interest.

Ethical approval This research involved no human participants and/ or animals.

\section{References}

1. Ahuja I, Kissen R, Bones AM (2012) Phytoalexins in defense against pathogens. Trends Plant Sci 17:73-90. https://doi.org/10.1016/j.tplants.2011.11.002

2. Bastani S, Hajiboland R, Khatamian M, Saket Oskoui M (2018) Nano iron (Fe) complex is an effective source of Fe for tobacco plants grown under low Fe supply. J Soil Sci Plant Nut 18(2):524-541. https://doi.org/10.4067/S0718-95162018005001602

3. Bendary E, Francis RR, Ali HMG, Sarwat MI, El Hady S (2013) Antioxidant and structure-activity relationships (SARs) of some phenolic and anilines compounds. Ann Agric Sci 58:173-181. https://doi.org/10.1016/j.aoas.2013.07.002

4. Blanch GP, Gómez-Jiménez MC, Del Castillo MLR (2020) Exogenous Ssalicylic acid improves phenolic content and antioxidant activity in table grapes. Plant Foods Hum Nutr 75(2):177-183. https://doi.org/10.1007/s11130-019-00793-z

5. Cesco S, Neumann G, Tommasi N, Pinton R, Weisskopf L (2010) Release of plant borne flavonoids into the rhizosphere and their role in plant nutrition. Plant Soil 329:1-25. https://doi.org/10.1007/s11104-009-0266-9

6. Cosetang MY, Lee CY (1978) Changes in apple polyphenol oxidase and polyphenol concentrations in relation to degree of browning. J Food Sci 52985-988. https://doi.org/10.1111/j.1365-2621.1987.tb14257.x

7. Côté J, Caillet S, Doyon G, Sylvain JF, Lacroix M (2010) Bioactive compounds in cranberries and their biological properties. Crit Rev Food Sci Nutr 50:666-679. https://doi.org/10.1080/10408390903044107

8. Davies NW (1990) Gas chromatographic retention indices of monoterpenes and sesquiterpenes on methylsilicon and carbowax 20M Phases. J Chromatogr A 503:1-24. https://doi.org/10.1016/S0021-9673(01)81487-4

9. Garagounis C, Beritza K, Georgopoulou ME, Sonawane P, Haralampidis K, Goossens A, Aharoni A, Papadopoulou KK (2020) A hairy-root transformation protocol for Trigonella foenum-graecum $\mathrm{L}$. as a tool for metabolic engineering and specialised metabolite pathway elucidation. Plant Physiol Biochem 154:451-462. https://doi.org/10.1016/j.plaphy.2020.06.011

10. Ghararia Z, Bagheria K, Danafar H, Sharafi A (2020) Enhanced flavonoid production in hairy root cultures of Scutellaria bornmuelleri by elicitor induced over-expression of MYB7 and FNSח2 genes. Plant Physiol Biochem 148:35-44.

https://doi.org/10.1016/j.plaphy.2020.01.002

11. Ghasemi R, Mirahmadi-zare SZ, Nasr-Esfahani MH, Allafchian A, Behmanesh M (2019) Optical biosensing of Streptococcus agalactiae based on core/shell magnetic nanoparticle-quantum dot. Anal Bioanal Chem 411:6733-6743. https://doi.org/10.1007/s00216-019-02046-z

12. Ghasemzadeh A, Jaafar HZE, Karimi E (2012) Involvement of salicylic acid on antioxidant and anticancer properties, anthocyanin production and chalcone synthase activity in ginger (Zingiber officinale Roscoe) varieties. Int J Mol Sci 13:1482814844. https://doi.org/10.3390/ijms131114828

13. Ghorbanpour M, Hadian J (2015) Multi-walled carbon nanotubes stimulate callus induction, secondary metabolites biosynthesis and antioxidant capacity in medicinal plant Satureja khuzestanica grown in vitro. Carbon 94:749-759. https://doi.org/10.1016/j.carbon.2015.07.056

14. Goldson A, Lam M, Scaman CH, Clemens S, Kermode A (2008) Screening of phenylalanine ammonia lyase in plant tissues and retention of activity during dehydration. J Sci Food Agric 88:619-625. https://doi.org/10.1002/jsfa.3126

15. Hedayati A, Hosseini B, Palazon J, Maleki R (2020) Improved tropane alkaloid production and changes in gene expression in hairy root cultures of two Hyoscyamus species elicited by silicon dioxide nanoparticles. Plant Physiol Biochem 155:416-428. https://doi.org/10.1016/j.plaphy.2020.07.029

16. Hu S, Yin J, Nie S, Wang J, Phillips GO, Xie M, Cui SW (2016) In vitro evaluation of the antioxidant activities of carbohydrates. Bioact Carbohydr Diet Fibre 7:19-27. https://doi.org/10.1016/j.bcdf.2016.04.001

17. Huang R, Xia R, Lu Y, Hu L, Xu Y (2008) Effect of pre-harvest salicylic acid spray treatment on post-harvest antioxidant in the pulp and peel of 'Cara cara' navel orange (Citrus sinenisis L. Osbeck). J Sci Food Agric 88(2):229-236.

Page $14 / 21$ 
https://doi.org/10.1002/jsfa.3076

18. Idrees M, Khan MMA, Aftab T, Naeem M, Hashmi N (2010) Salicylic acid-induced physiological and biochemical changes in lemongrass varieties under water stress. J Plant Interact 5:293-303. https://doi.org/10.1080/17429145.2010.508566

19. Kastell A, Zrenner R, Schreiner M, Kroh L, Ulrichs C, Smetanska I, Mewis I (2015) Metabolic engineering of aliphatic glucosinolates in hairy root cultures of Arabidopsis thaliana. Plant Mol Biol Rep 33:598-608. https://doi.org/10.1007/s11105014-0781-6

20. Khaleel C, Tabanca N, Buchbauer G (2018) a-Terpineol, a natural monoterpene: A review of its biological properties. Open Chem 16(1):349-361. https://doi.org/10.1515/chem-2018-0040

21. Li XM, Tian SL, Pang ZC (2009) Extraction of Cuminum cyminum essential oil by combination technology of organic solvent with low boiling point and system distillation. Food Chem 115:1114-1119. https://doi.org/10.1016/j.foodchem.2008.12.091

22. Meda A, Lamien CE, Romito M, Millogo J, Nacoulma OG (2005) Determination of the total phenolic, flavonoid and proline contents in Burkina Fasan honey, as well as their radical scavenging activity. Food Chem 91:571-577. https://doi.org/10.1016/j.foodchem.2004.10.006

23. Mendoza D, Cuaspud O, Arias JP, Ruiz O, Arias M (2018) Effect of salicylic acid and methyl jasmonate in the production of phenolic compounds in plant cell suspension cultures of Thevetia peruviana. Biotechnol Rep 3:e00273. https://doi.org/10.1016/j.btre.2018.e00273

24. Miliauskas G, Venskutonis PR, Van Beek TA (2004) Screening of radical scavenging activity of some medicinal plants and aromatic plant extract. Food Chem 85:231-237. https://doi.org/10.1016/j.foodchem.2003.05.007

25. Mohasseli V, Farbood F, Moradi A (2020) Antioxidant defense and metabolic responses of lemon balm (Melissa officinalis L.) to Fe-nano-particles under reduced irrigation regimes. Ind Crops Prod 149:112338. https://doi.org/10.1016/j.indcrop.2020.112338

26. Mozafari AA, Havas F, Ghaderi N (2018) Application of iron nanoparticles and salicylic acid in in vitro culture of strawberries (Fragaria $\times$ ananassa Duch.) to cope with drought stress. Plant Cell Tissue Organ Cult 132:511-523. https://doi.org/10.1007/s11240-017-1347-8

27. Murashige T, Skoog F (1962) A revised medium for rapid growth and bioassays with tobacco tissue cultures. Plant Physiol 15:473-497. https://doi.org/10.1111/j.1399-3054.1962.tb08052.x

28. Murti Y, Yogi B, Pathak D (2010) Pharmacognostic standardization of leaves of Calotropis procera(Ait.) R. Br. (Asclepiadaceae). Int J Ayurveda Res 1:14-17. https://doi.org/10.4103/0974-7788.59938

29. Nostro A, Papalia T (2012) Antimicrobial activity of carvacrol: current progress and future prospectives. Recent Pat Antiinfect Drug Discov 7:28-35. https://doi.org/10.2174/157489112799829684

30. Nourozi E, Hosseini B, Maleki R, Mandoulakani BA (2019) Iron oxide nanoparticles: a novel elicitor to enhance anticancer flavonoid production and gene expression in Dracocephalum kotschyi hairy-root cultures. J Sci Food Agric 99(14):6418-6430. https://doi.org/10.1002/jsfa.9921

31. Rastogi A, Zivcak M, Sytar O, Kalaji HM, He X, Mbarki S, Brestic M (2017) Impact of metal and metal oxide nanoparticles on plant: a critical. Review Front Chem 5:78. https://doi.org/10.3389/fchem.2017.00078

32. Razavizadeh R, Farahzadianpoor F, Adabavazeh F, Komatsu S (2019) Physiological and morphological analyses of Thymus vulgaris L. in vitro cultures under polyethylene glycol (PEG)-induced osmotic stress. In Vitro Cell Dev Biol Plant 55:342-357. https://doi.org/10.1007/s11627-019-09979-1

33. Rezaei A, Ghanati F, Behmanesh M (2010) Static magnetic field improved salicylic acid effect on taxol production in suspensioncultured hazel (Corylus avellana) cells. In: 6th International workshop on biological effects of electromagnetic fields 70-71

34. Ronald SF, Laima SK (1999) Phenolics and cold tolerance of Brassica napus. Department of Plant Agriculture. Google Schlar, Ontario

35. Sharma P, Jha AB, Dubey RS, Pessarakli M (2012) Reactive oxygen species, oxidative damage, and antioxidative defense mechanism in plants under stressful conditions. J Bot 1-26. https://doi.org/10.1155/2012/217037

36. Shih PH, Chan YC, Liao JW, Wang MF, Yen GC (2010) Antioxidant and cognitive promotion effects of anthocyanin-rich mulberry (Morus atropurpurea L.) on senescence-accelerated mice and prevention of Alzheimer's disease. J Nutr Biochem 21:598-605. https://doi.org/10.1016/j.jnutbio.2009.03.008

Page $15 / 21$ 
37. Shokrollahi S, Ghanati F, Sajedi RH, Sharifi M (2018) Possible role of iron containing proteins in physiological responses of soybean to static magnetic field. J plant physiol 226:163-171. https://doi.org/10.1016/j.jplph.2018.04.018

38. Tato L, De Nisi P, Donnini S, Zocchi G (2013) Low iron availability and phenolic metabolism in a wild plant species (Parietaria judaica L.). Plant Physiol Biochem 72:145-153. https://doi.org/10.1016/j.plaphy.2013.05.017

39. Thilip C, Mehaboob VM, Varutharaju K, Faizal K, Raja P, Aslam A, Shajahan A (2019) Elicitation of withaferin-A in hairy root culture of Withania somnifera (L.) Dunal using natural polysaccharides. Biologia 74:961-968. https://doi.org/10.2478/s11756019-00236-9

40. Thiruvengadam M, Praveen N, Maria John KM, Yang YS, Kim SH, Chung IM (2014) Establishment of Momordica charantia hairy root cultures for the production of phenolic compounds and determination of their biological activities. Plant Cell Tissue Organ Cult 118:545-557. https://doi.org/10.1007/s11240-014-0506-4

41. Vallianou I, Peroulis N, Pantazis P, Hadzopoulou-Cladaras M (2011) Camphene, a plant-derived monoterpene, reduces plasma cholesterol and triglycerides in hyperlipidemic rats independently of HMG-CoA reductase activity. PLoS ONE 6:e20516. https://doi.org/10.1371/journal.pone.0020516

42. Wagner GJ (1979) Content and vacuole/extra vacuole distribution of neutral sugars, free amino acids and anthocyanins in protoplast. Plant Physiol 64:88-93. https://doi.org/10.1104/pp.64.1.88

43. Wannoussa W, Masy T, Lambert SD, Heinrichs B, Tasseroul L, Al-Ahmad A, Weekers F, Thonar P, Hiligsmann S (2015) Effect of iron nanoparticles synthesized by a Sol-Gel process on Rhodococcus erythropolis T902.1 for biphenyl degradation. J Water Resource Prot (JWARP) 7:264-277. https://doi.org/10.4236/jwarp.2015.73021

44. Wu YL, Wang DN (2009) A new class of natural glycopeptides with sugar moiety-dependent antioxidant activities derived from Ganoderma lucidum, fruiting bodies. J Proteome Res 8:436-442. https://doi.org/10.1021/pr800554w

45. Yan Q, Shi M, Ng J, Wu JY (2006) Elicitor-induced rosmarinic acid accumulation and secondary metabolism enzyme activities in Salvia miltiorrhiza hairy roots. Plant Sci 170:853-858. https://doi.org/10.1016/j.plantsci.2005.12.004

46. Yang D, Hu J, Fu S (2009) Controlled synthesis of magnetite-silica nanocomposites via a seeded sol-gel approach. J Phys Chem C 113(18):7646-7651. https://doi.org/10.1021/jp900868d

47. Zhuang H, Du J, Wang Y (2011) Antioxidant capacity changes of 3 cultivar Chinese pomegranate (Punica granatum L.) juices and corresponding wines. J Food Sci 76(4):C606-C611. https://doi.org/10. 1111/j.1750-3841.2011.02149.x

48. Zucker M (1965) Induction of phenylalanine deaminase by light and its relation to chlorogenic acid synthesis in potato tuber tissue. Plant Physiol 40:779. https://doi.org/10.1104/pp.40.5.779

\section{Figures}




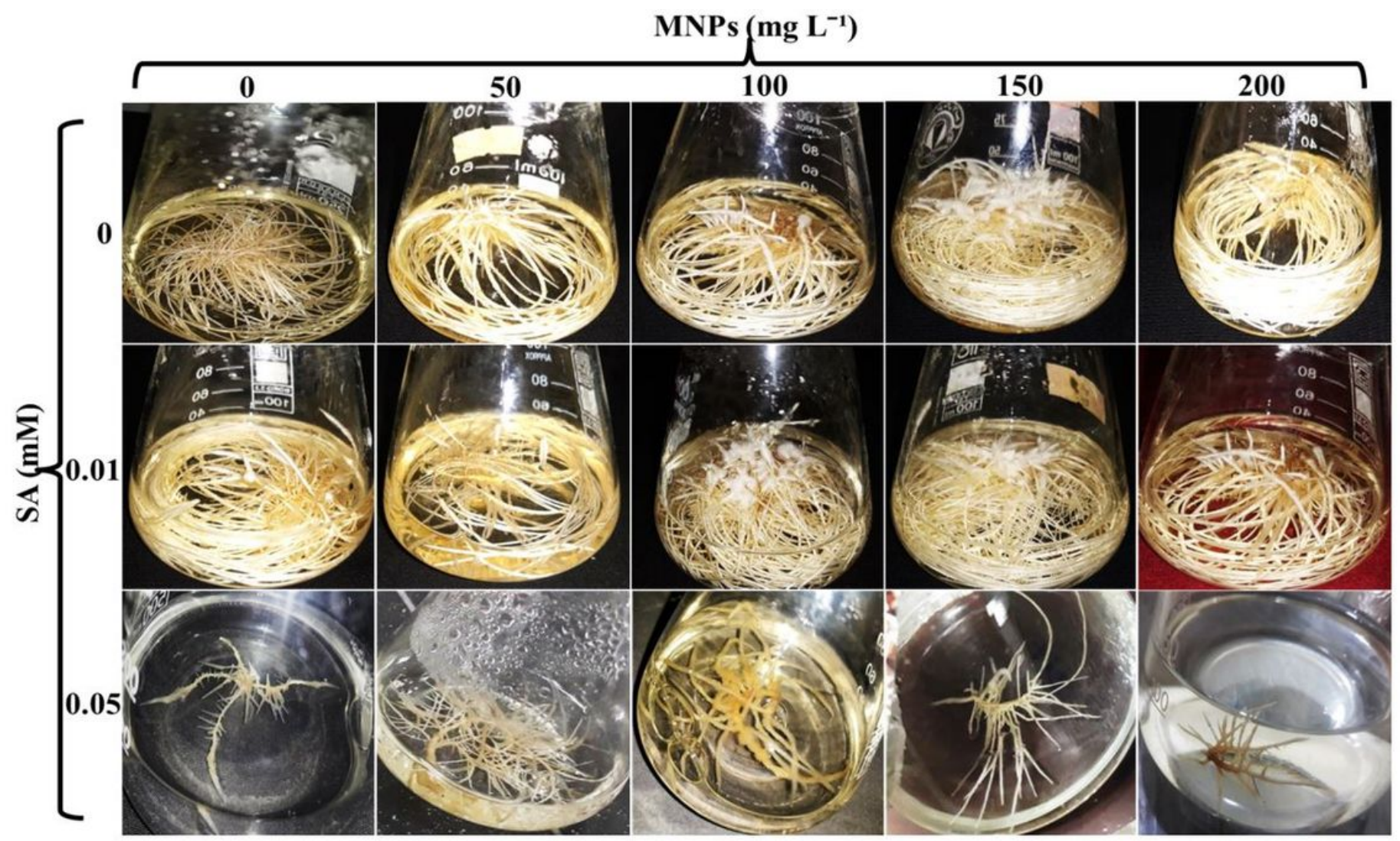

Figure 1

Phenotype of hairy roots of $C$. procera treated with different concentrations of magnetic nanoparticle (MNP) and salicylic acid (SA). Hairy roots were treated with 50,100,150, and $200 \mathrm{mg} \mathrm{L}^{-1} \mathrm{MNPs}$ and $0,0.01$ and $0.05 \mathrm{mM} \mathrm{SA}$ for 72 hours, and then transferred into elicitor-free MS liquid medium for 21 days. 

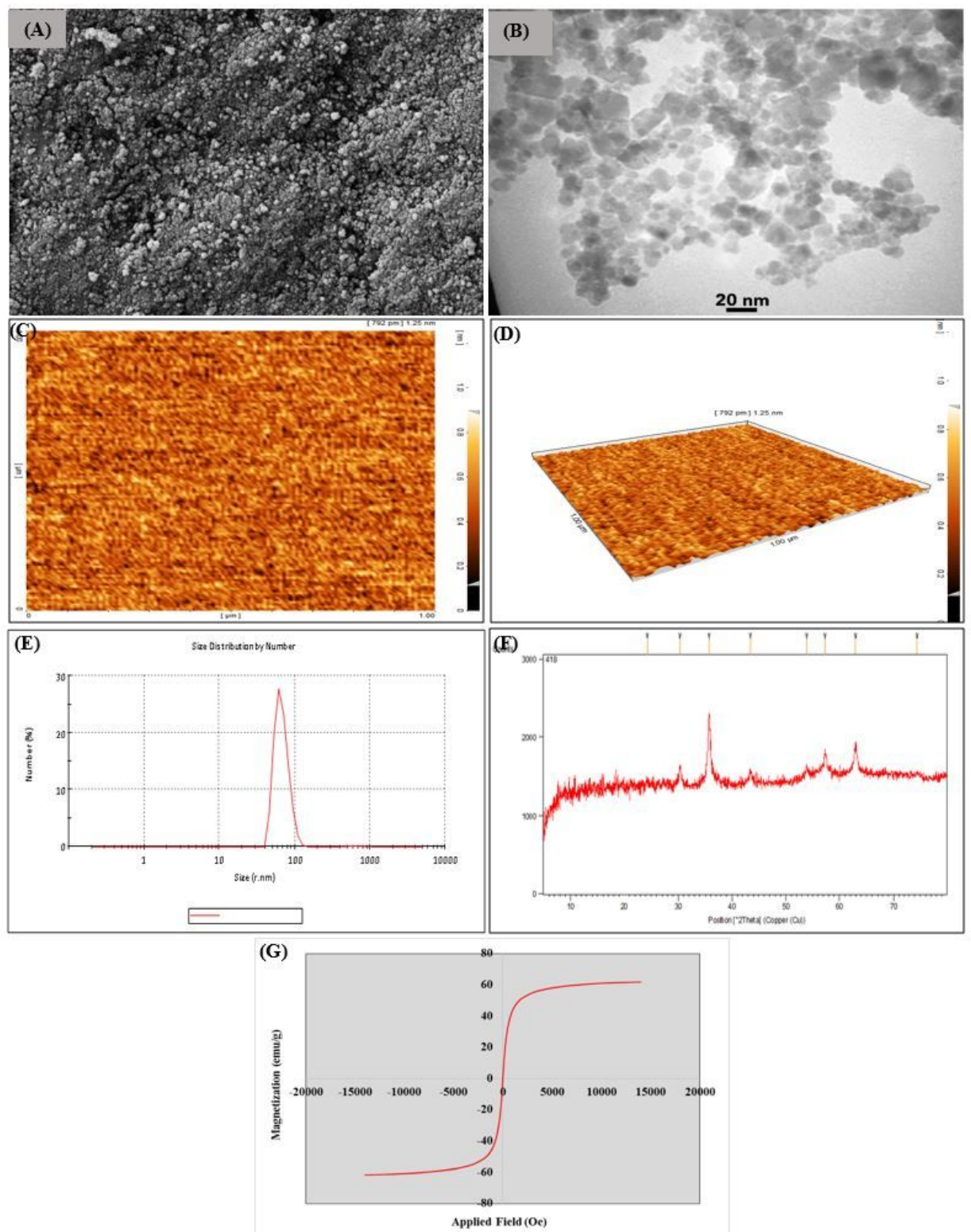

\section{Figure 2}

SEM (A) and (B) TEM images, two -dimensional (C) and three-dimensional (D) AFM images, DLS (E), XRD pattern (F), and hysteresis loop $(G)$ of magnetic nanoparticles 

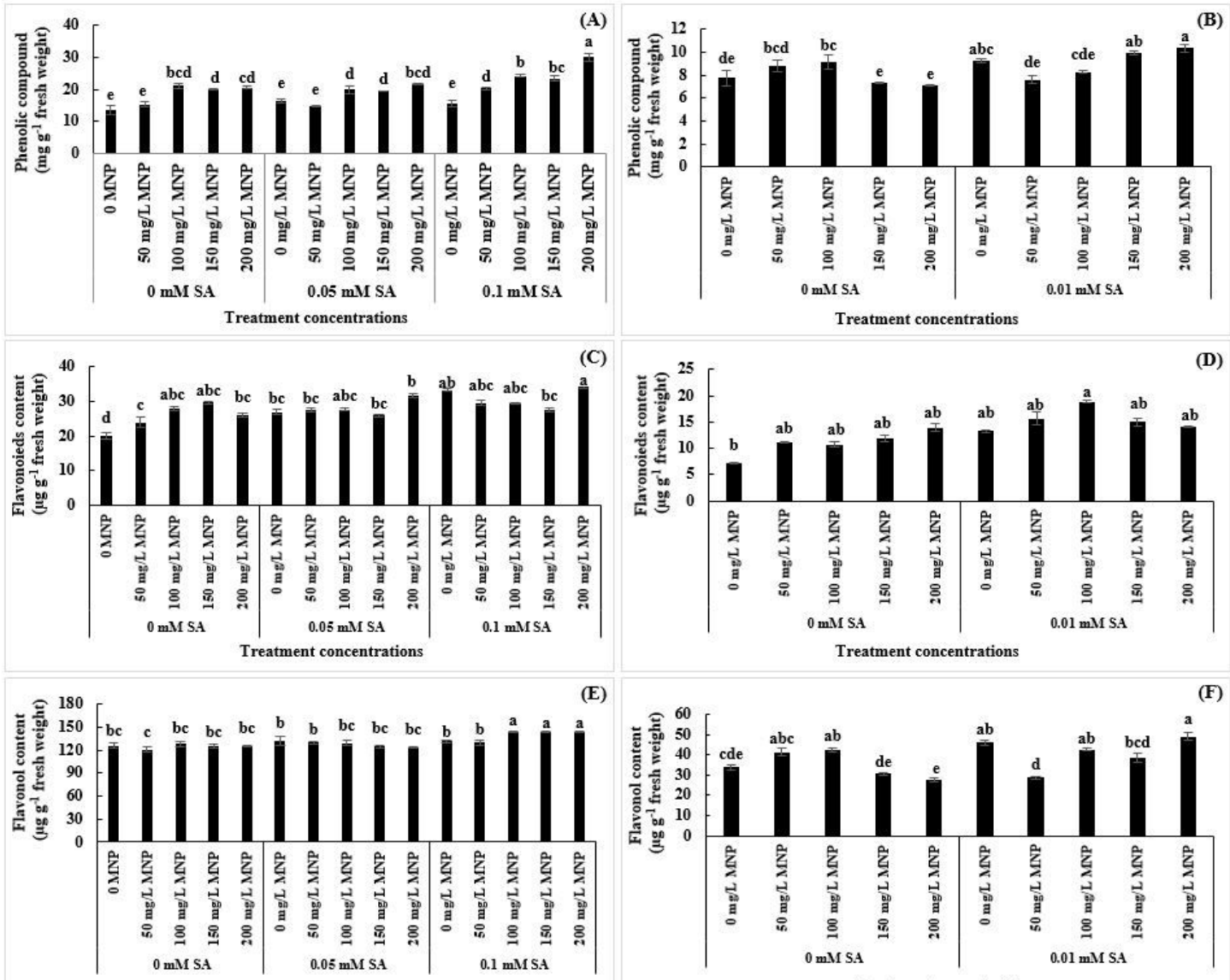

Treatment concentrations

Treatment concentrations

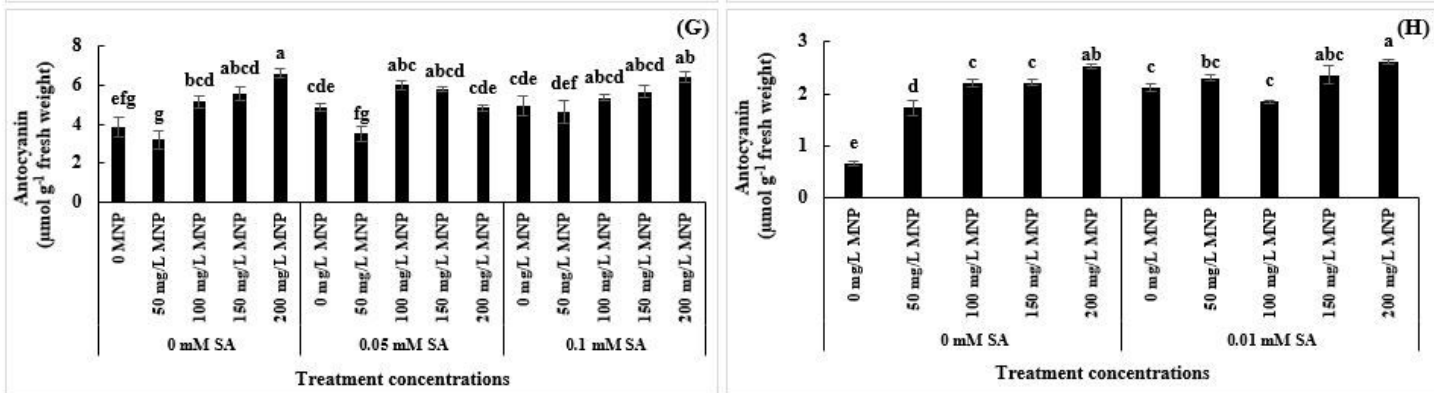

Figure 3

Comparison of secondary metabolites in leaf and hairy root of $C$. procera treated with different concentrations of magnetic nanoparticle (MNP) and salicylic acid (SA). 21-day-old seedlings were treated with 0, 50, 100, 150, and $200 \mathrm{mg} \mathrm{L}^{-1} \mathrm{MNPs}$ and 0.0 , 0.05 and $0.1 \mathrm{mM} \mathrm{SA}$ every other day up to 2 weeks. Moreover, hairy roots were treated with above-mentioned concentrations of MNPs and 0 and $0.01 \mathrm{mM} \mathrm{SA} \mathrm{for} 72$ hours, and then transferred into elicitor-free MS liquid medium for 21 days. After treatment, total phenolic (A-B), flavonoids (C-D), flavonol (E-F) and anthocyanin (G-H) in leaf and hairy roots were measured, respectively. Values represent the mean of three replicates and dissimilar letters are significantly different according to Duncan's test $(P \leq 0.05)$. 


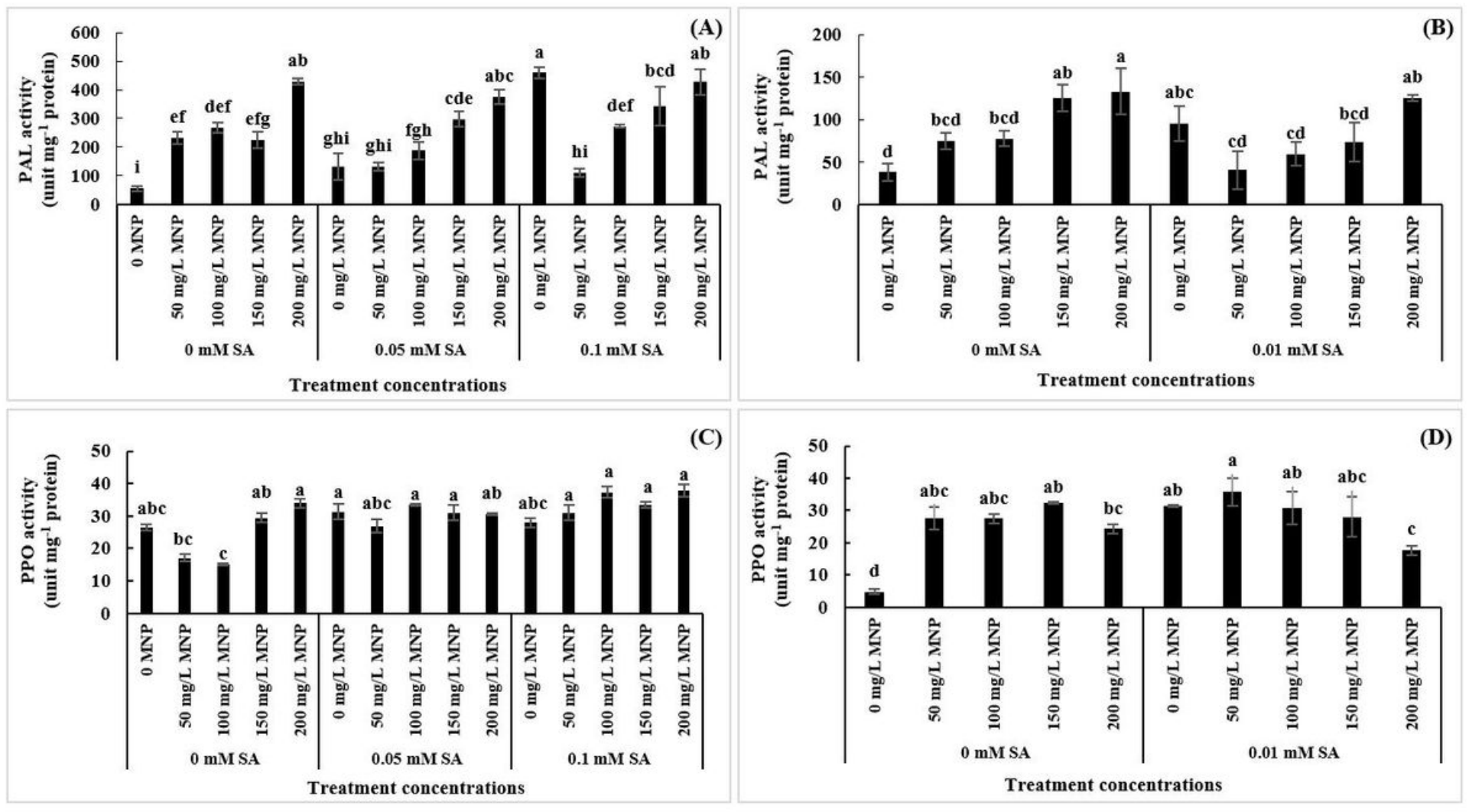

Figure 4

Comparison of enzymatic activities of phenylalanine ammonia lyase (PAL) and polyphenol oxidase (PPO) in leaf and hairy root of $C$. procera treated with different concentrations of magnetic nanoparticle (MNP) and salicylic acid (SA). 21-day-old seedlings were treated with $0,50,100,150$, and $200 \mathrm{mg} \mathrm{L}^{-1} \mathrm{MNPs}$ and $0.0,0.05$ and $0.1 \mathrm{mM} \mathrm{SA}$ every other day up to 2 weeks. Moreover, hairy roots were treated with above-mentioned concentrations of MNPs and 0 and $0.01 \mathrm{mM}$ SA for 72 hours, and then transferred into elicitorfree MS liquid medium for 21 days. After treatment, PAL (A-B) and PPO activities (C-D) in leaf and hairy roots were measured, respectively. Values represent the mean of three replicates and dissimilar letters are significantly different according to Duncan's test $(P \leq 0.05)$. 

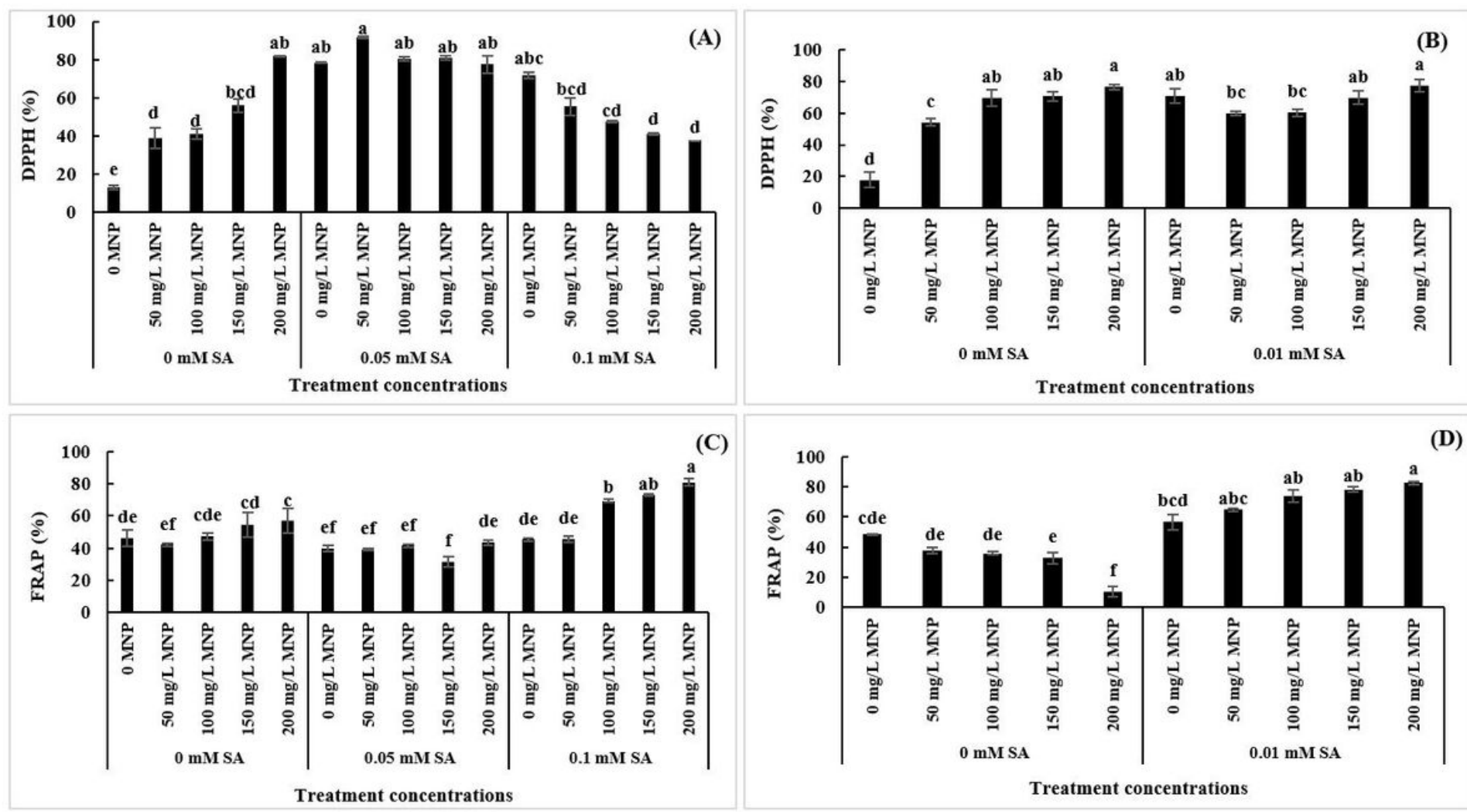

Figure 5

Comparison of 2, 2-diphenyl-1-picrylhydrazyl (DPPH) and ferric-reducing antioxidant power (FRAP) in leaf and hairy root of $C$. procera treated with different concentrations of magnetic nanoparticle (MNP) and salicylic acid (SA). 21-day-old seedlings were treated with $0,50,100,150$, and $200 \mathrm{mg} \mathrm{L}^{-1} \mathrm{MNPs}$ and $0.0,0.05$ and $0.1 \mathrm{mM}$ SA every other day up to 2 weeks. Moreover, hairy roots were treated with above-mentioned concentrations of MNPs and 0 and $0.01 \mathrm{mM}$ SA for 72 hours, and then transferred into elicitorfree MS liquid medium for 21 days. After treatment, DPPH (A-B) and FRAP (C-D) in leaf and hairy roots were measured, respectively. Values represent the mean of three replicates and dissimilar letters are significantly different according to Duncan's test $(P \leq 0.05)$. 